\title{
Rzeźba granitowego skalnego miasta Starościńskich Skał w Rudawach Janowickich (Sudety Zachodnie)
}

\author{
Morphology of the granite rock city of Starościńskie Skały in the Rudawy Janowickie \\ (Western Sudetes)
}

\author{
Aleksandra Michniewicz , Kacper Jancewicz, Milena Różycka, Piotr Migoń \\ Instytut Geografii i Rozwoju Regionalnego, Uniwersytet Wrocławski, Wrocław, Polska; *aleksandra.michniewicz@uwr.edu.pl
}

\begin{abstract}
Zarys treści: Praca zawiera opis grupy Starościńskich Skał w północnej części Rudaw Janowickich, która stanowi jedyny w polskich Sudetach przykład granitowego „skalnego miasta”. Starościńskie Skały to złożona forma ostańcowa, składająca się z szeregu skałek usytuowanych na granitowym cokole o cechach wzgórza wyspowego. Wyniki kartowania terenowego zostały przedstawione na szczegółowej mapie geomorfologicznej, zawierającej 30 wydzieleń. Głównym czynnikiem odpowiedzialnym za rzeźbę skałek jest zróżnicowany system spękań (koncentryczny i prostokątny), do którego nawiązuje dwudzielność kompleksu skalnego. Cechą charakterystyczną tej grupy skalnej jest występowanie bogatej mikrorzeźby, która świadczy o jej stabilności i długim rozwoju powierzchniowym. Niektóre elementy mikrorzeźby nisze kloszowe - dowodzą jednak tego, że w pierwszym etapie rozwoju skałki były kształtowane podpowierzchniowo, przy istotnym udziale wietrzenia chemicznego.
\end{abstract}

Słowa kluczowe: formy rzeźby granitowej, skalne miasto, wietrzenie granitu, spękania, Sudety

\begin{abstract}
The paper presents a description of the Starościńskie Skały tor group located in the northern part of the Rudawy Janowickie which is the only example of a granite rock city in the Polish Sudetes. Starościńskie Skały is a specific complex landform composed of various tors situated on a dome-like pedestal. The results of detailed field landform mapping are presented on geomorphological map, which contains 30 elements. The major factor influencing morphology of the Starościńskie Skały is a complex system of joints (sheeting and orthogonal joints) which control the shape of the residual and are responsible for morphological duality of the rock city. A characteristic feature of this tor group is the presence of varied microrelief, which indicates surface stability and protracted development at the surface. However, certain components of microrelief - flared slopes - are an evidence of subsurface chemical weathering of Starościńskie Skały tor group in the first stage of their development.
\end{abstract}

Key words: granite landforms, rock city, granite weathering, jointing patterns, Sudetes

\section{Wprowadzenie}

Zachodnia część Sudetów to obszar, który w znacznej części zbudowany jest z granitoidów. Rozwój rzeźby na granitowym podłożu wynika głównie z lokalnych cech struktury geologicznej, takich jak układ spękań oraz litologia. Wpływ struktury granitu na kształtowanie się morfologii Kotliny Jeleniogórskiej wraz z otoczeniem został po raz pierwszy zasygnalizowany w latach 60 . XX w., kiedy to powiązano różnice w składzie petrograficznym skał z ich odpornością na niszczenie (Dumanowski 1963, 1968). Kolejne badania $\mathrm{w}$ zakresie relacji między strukturą granitu a jego rzeźbą prezentowały bardziej szczegółowe i syntetyczne podejście (Migoń 1996, 2007). Wpływ litologii na rozwój form został w nich omówiony w oparciu o analizę indywidualnych przykładów w różnych skalach przestrzennych.

Elementy rzeźby ostańcowej wykształcone w granitach plutonu karkonosko-izerskiego mają odmienną morfologię $\mathrm{w}$ zależności od różnic petrograficznych. Skałki zbudowane z równoziarnistej odmiany granitu dominują na grzbietach Karkonoszy i składają się głównie z regularnych, kanciastych bloków (Berg 1927, Jahn 1962, 1974, Migoń 2005). Odmiana porfirowata odznacza się zróżnicowaną strukturą we- 
wnętrzną, która przyczyniła się do rozwoju bardziej urozmaiconej rzeźby i powstania zarówno większych form rezydualnych - wzgórz ostańcowych o charakterze wyspowym, niekiedy przypominających kopuły (Migoń 1993, 2012), jak i skałek o nieregularnych kształtach (Jahn 1962).

Obszarem szczególnie obfitującym w granitowe formy skałkowe jest północna część Rudaw Janowickich (ryc. 1), które znajdują się w północno-wschodniej części masywu karkonosko-izerskiego. Formy skałkowe rozwinęły się na podłożu granitowym o strukturze porfirowatej. Należą do nich także położone na szczycie Lwiej Góry Starościńskie Skały, będące formacją typu „skalnego miasta”. Starościń- skie Skały to zgrupowanie, składające się z szeregu granitowych ostańców, rozdzielonych szczelinami i korytarzami, które razem tworza rozbudowany, unikatowy w skali Sudetów Zachodnich skalny labirynt. Swoim zasięgiem i układem nie przypominają one innych zgrupowań granitowych skałek tak licznie występujących na obszarze masywu karkonosko-izerskiego, lecz duży kompleks skalny o hierarchicznej budowie wewnętrznej, rozciągający się na prawie 200 m długości. W obrębie Rudaw Janowickich występują formy skałkowe zazwyczaj składające się z pojedynczych grzęd, murów lub baszt skalnych, które wyrastają bezpośrednio z powierzchni stoku lub grzbietu. Szczytowa część Lwiej Góry ma niektóre cechy gra-

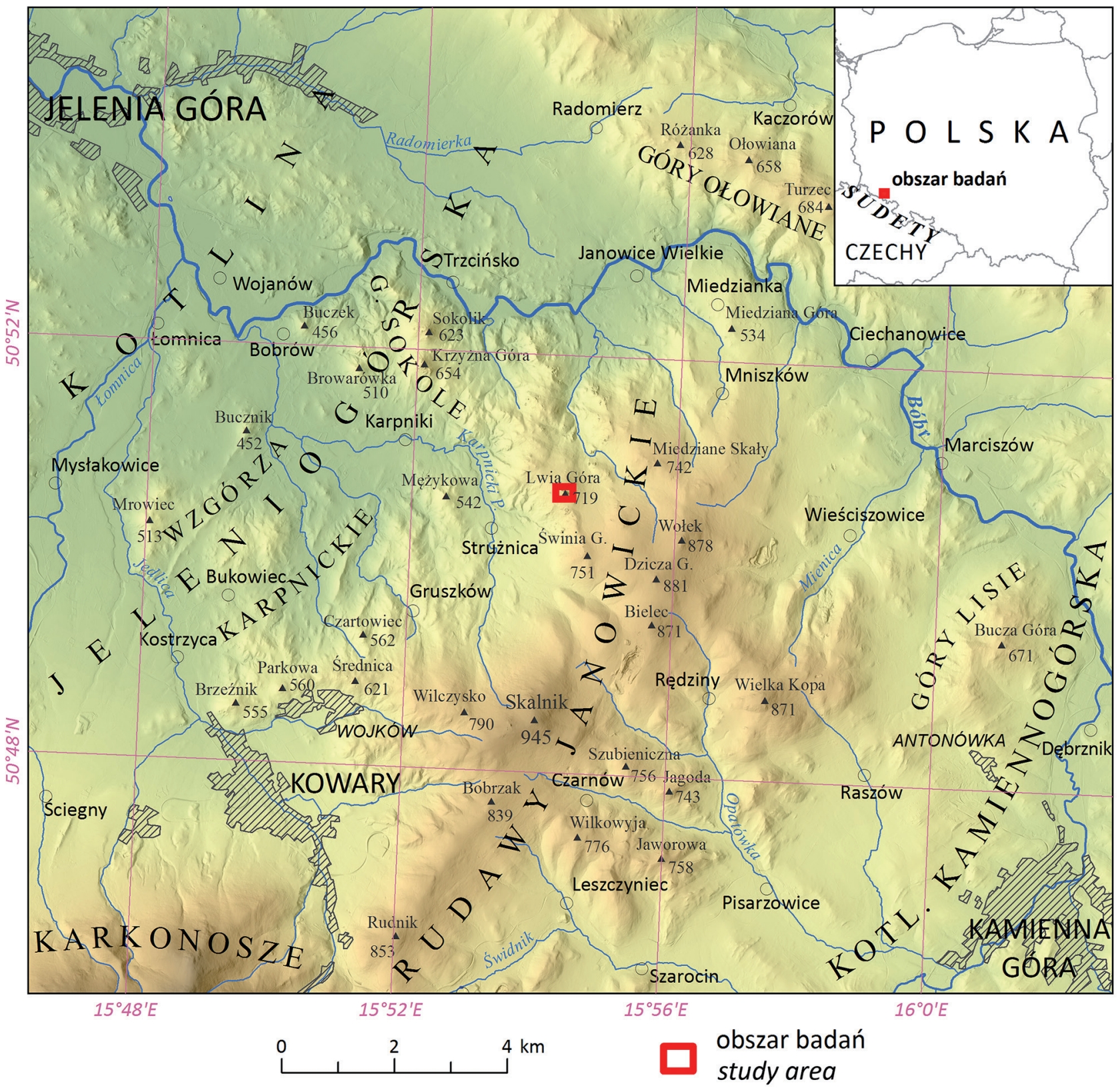

Ryc. 1. Lokalizacja obszaru badań na tle Sudetów

Fig. 1. Location of the study area within the Sudetes 
nitowej kopuły, przez której dezintegrację powstały liczne formy skałkowe, jednak morfologicznie nie nie jest ona typowym samodzielnym kopulastym wzgórzem, którego przykłady znajdują się $\mathrm{w}$ dnie sąsiadującej Kotliny Jeleniogórskiej (np. Witosza; Migoń 1992, 1993). O wyjątkowości Starościńskich Skał w skali polskich Sudetów świadczy również fakt, że tworzą one jedyny tego typu kompleks skalny rozwinięty w granicie. Skalne miasta znane są $\mathrm{w}$ Sudetach głównie $z$ obszarów zbudowanych $z$ piaskowców, np. Błędne Skały i Szczeliniec Mały w Górach Stołowych (Czeppe 1952) oraz Adršpašsko-teplické skály w Republice Czeskiej (Vítek 2016).

Skałki na szczycie Lwiej Góry cieszą się dużą popularnością turystyczną. Już w pierwszej połowie XIX w. dostrzeżono atrakcyjność tego miejsca, które zostało włączone (podobnie jak bardziej znane Góry Sokole) do parku krajobrazowego, towarzyszącego rezydencji królewskiej w pobliskich Karpnikach. Obecnie Starościńskie Skały są wzmiankowane $\mathrm{w}$ regionalnych przewodnikach turystycznych (Steć 1965), geoturystycznych (Stachowiak i in. 2013, Migoń, Łętkowska 2015) oraz wspinaczkowych, jednak nie zostały kompleksowo zbadane oraz opisane $\mathrm{w}$ literaturze. Największe formy skałkowe tego „skalnego miasta” zyskały nazwy własne. Są nimi Starościńska Igła, Starościńska Skała, Widokowa i Skałka Marianny położone w południowo-wschodniej części grupy oraz skałka Krzywa, znajdująca się w północno-zachodniej części.

W literaturze polskiej problematyka geomorfologii ostańców rozwiniętych na podłożu granitowym była poruszana w niewielu pracach, które dotyczyły genezy skałek (Jahn 1962), gór wyspowych (Migoń 1992, 1993, 1997) lub mniejszych form w ich obrębie (Czerwiński, Migoń 1993). „Skalne miasta”, które są formami niższego rzędu niż wzgórza ostańcowe, nie były dotąd obiektem wnikliwych badań geomorfologicznych. Tego typu formy, które cechują się złożoną strukturą wewnętrzną, są interesujące i często osobliwym przykładem form rzeźby denudacyjnej.

Celem artykułu jest szczegółowa charakterystyka nietypowej granitowej rzeźby skalnej, w tym przedstawienie dokładnej mapy geomorfologicznej oraz porównanie tego typu rzeźby $z$ innymi podobnymi formami na terenie Sudetów. Wyniki prac inwentaryzacyjno-kartograficznych nad rzeźbą Starościńskich Skał posłużyły również jako podstawa interpretacji uwarunkowań rozwoju skałek oraz koncepcji morfogenezy „skalnego miasta”.

\section{Źródła danych i metody badań}

Analiza rzeźby przeprowadzona została w oparciu o cyfrowy model wysokościowy ${ }^{1}$ (DEM) o wysokiej

Model udostępniony przez Centralny Ośrodek Dokumentacji rozdzielczości $(1 \times 1 \mathrm{~m})$, a zbudowany na podstawie danych wysokościowych pochodzących z lotniczego skaningu laserowego (ang. LiDAR, Light Detection and Ranging). Gęstość źródłowej chmury punktów wynosi 4-6 pkt $/ \mathrm{m}^{2}$, średni błąd wysokości modelu nie przekracza 0,2 m, a błąd maksymalny - 0,3 m (Wężyk 2014). Ze względu na sposób opracowania modelu - odfiltrowanie i usuwanie punktów uznanych za reprezentujące elementy pokrycia terenu (roślinność, elementy infrastruktury) - istnieje możliwość występowania błędów wynikających z niewłaściwej klasyfikacji punktów (Sithole, Vosselman 2004). Przykładem może być eliminacja mniejszych form skalnych na obszarach leśnych (Migoń i in. 2013).

Dane cyfrowe posłużyły do wygenerowania mapy cieniowanego reliefu, a także map wybranych, wtórnych parametrów geomorfometrycznych, tj. nachyleń, ekspozycji oraz krzywizny profilowej, która dostarcza informacji o kształcie stoku (ryc. 2). Rozkład przestrzenny ostatniego z parametrów zobrazowany został dla danych o mniejszej rozdzielczości przestrzennej $(3 \times 3 \mathrm{~m}) \mathrm{w}$ celu eliminacji wpływu mniejszych/lokalnych nierówności terenu/załomów stokowych. Poszczególne warstwy rastrowe wygenerowane zostały przy użyciu oprogramowania SAGA-GIS 2.1.4.

Cyfrowy model wysokościowy o wysokiej rozdzielczości posłużył ponadto do wygenerowania podkładu poziomicowego (o cięciu poziomicowym równym $1 \mathrm{~m}$ ), który wykorzystano na etapie terenowego kartowania geomorfologicznego. Kartowanie to miało na celu weryfikację informacji dostarczonych przez dane cyfrowe, a także rejestrację mniejszych form rzeźby i ich elementów, nieosiągalnych $\mathrm{z}$ poziomu modelu (w tym mniejszych form wietrzeniowych oraz struktury utworów pokrywowych na stokach wokół ostańców skalnych). W efekcie kartowania terenowego powstała szczegółowa mapa geomorfologiczna $\mathrm{w}$ skali 1:1250 z legendą o łącznej liczbie 30 obiektów punktowych, liniowych i powierzchniowych. Mapa została opracowana przy użyciu oprogramowania ArcGIS 10.2 oraz pakietu graficznego Adobe CS6.

Pomiarów spękań - zmierzających do określenia kąta upadu oraz kierunku zapadania powierzchni nieciągłości - dokonano na pięciu stanowiskach pomiarowych (ryc. 4) z wykorzystaniem kompasu geologicznego. Łączna liczba pomiarów wyniosła 90, w tym przynajmniej 15 na pojedynczym stanowisku. Ich wyniki zaprezentowano $\mathrm{w}$ postaci diagramów biegunowych opracowanych za pośrednictwem programu Stereonet 9 (Allmendinger i in. 2012, Allmendinger 2013).

Geodezyjnej i Kartograficznej (CODGiK) w Warszawie. 

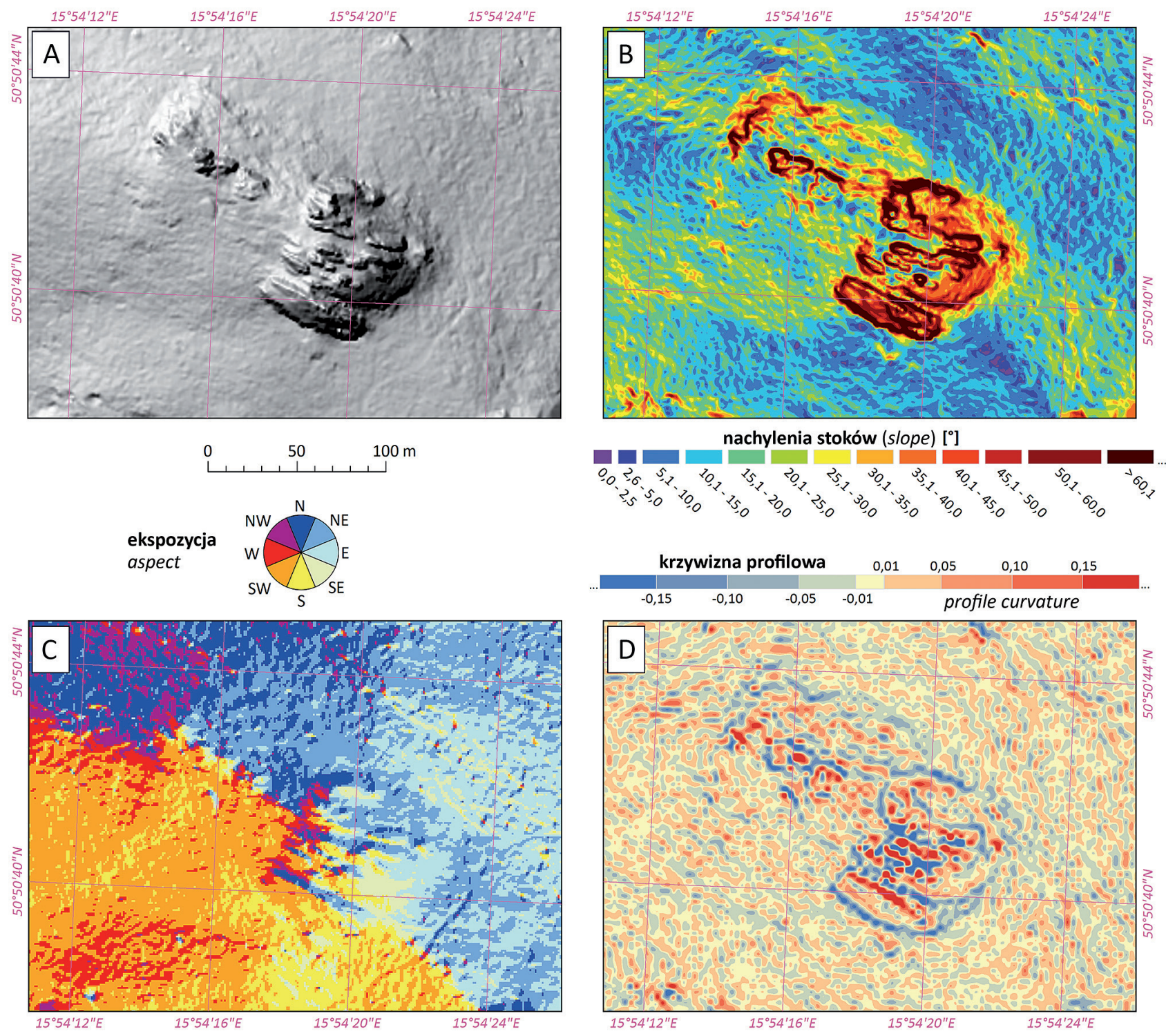

Ryc. 2. Wybrane cechy rzeźby Lwiej Góry

A - mapa cieniowanego reliefu, B - mapa spadków, C - mapa ekspozycji, D - krzywizna profilowa

Fig. 2. Selected relief features of the Mt Lwia Góra

A - hillshading relief map, B - slope map, C - aspect map, D - profile curvature map

\section{Obszar badań - rzeźba i budowa geologiczna}

Głównym elementem ukształtowania rzeźby północnej części Rudaw Janowickich jest kilka grzbietów rozchodzących się promieniście od zwornikowego szczytu Dziczej Góry, rozdzielonych nieckowatymi dolinami, niżej nabierającymi charakteru dolin wciosowych. Najbardziej zachodnim z tych grzbietów jest Janowicki Grzbiet, o długości około 5,5 km i łamanym przebiegu, generalnie w kierunku NW-SE. Jego wysokość obniża się od 881 m n.p.m. na Dziczej Górze po 475 m n.p.m. na Przełęczy Karpnickiej. Linia grzbietowa jest stosunkowo wyrównana, ze słabo zarysowanymi kulminacjami, a granitowe formy skałkowe, typowe dla północnej części Rudaw Janowic- kich, występują raczej na stokach niż w osi grzbietu. Wyjątkiem jest szczyt Lwiej Góry (ryc. 3), którego znaczną część zajmują Starościńskie Skały. Ku zachodowi Janowicki Grzbiet opada do kotliny Strużnicy, której dno jest położone na wysokości 420-460 m n.p.m., natomiast od strony wschodniej ogranicza go mało wyraźna niecka stokowa, niżej otwierająca się ku wciosowej dolinie Janówki. Różnica wysokości od strony wschodniej wynosi około $100 \mathrm{~m}$.

Lwia Góra wznosi się na wysokość 717 m n.p.m. i wyrasta około $30 \mathrm{~m}$ ponad powierzchnię linii grzbietowej w przyległych fragmentach. Ma charakter wydłużonej (ok. 200×100 m), ale w części wschodniej mocno rozczłonkowanej, skalistej kopuły. Około 100 $\mathrm{m}$ na południowy wschód $z$ niemal równej osi grzbietu wyrasta kolejne, ale znacznie mniejsze powierzch- 

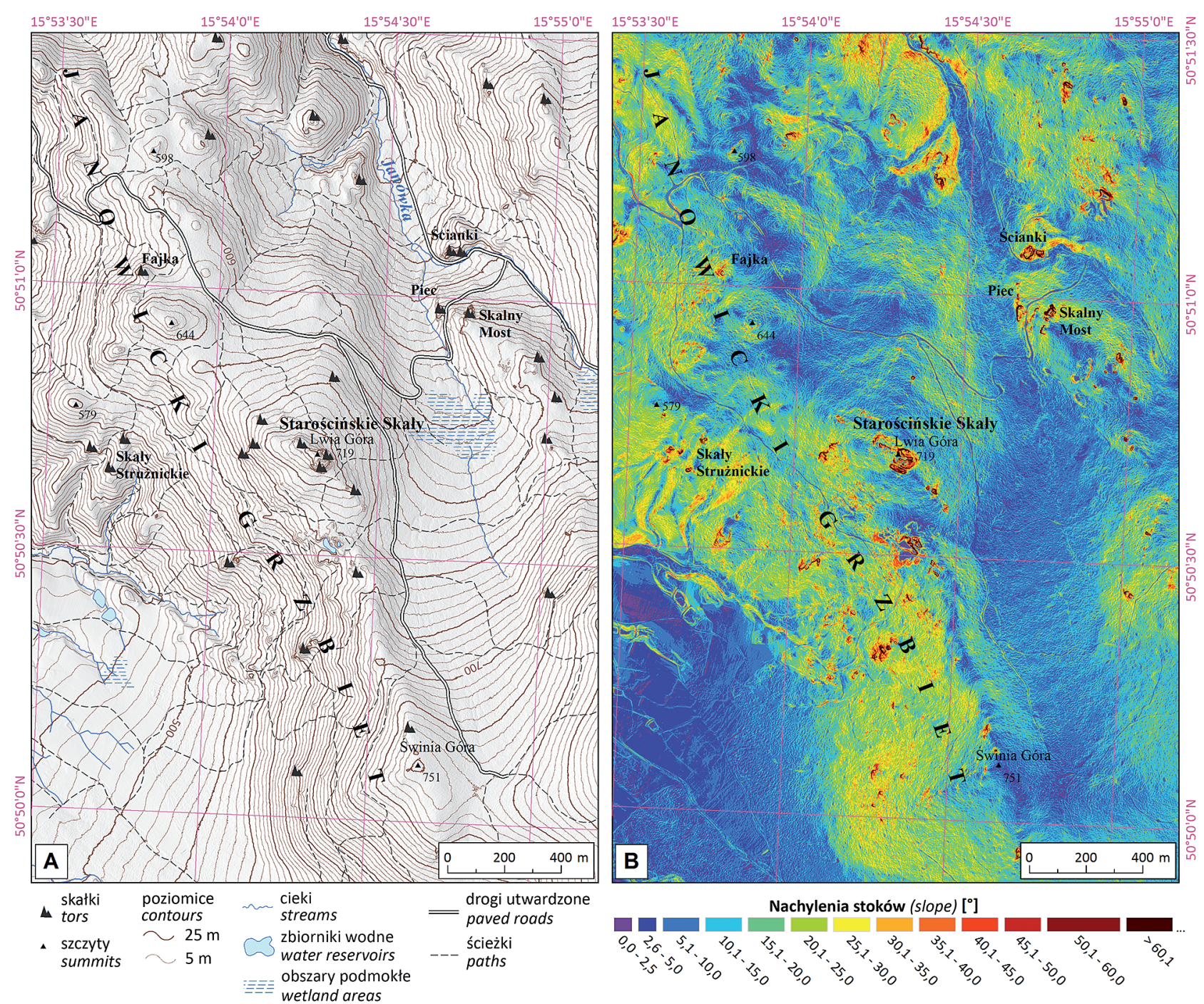

Ryc. 3. Położenie Starościńskich Skał na tle północnej części Rudaw Janowickich na mapie topograficznej (A) i mapie spadków (B)

Fig. 3. Location of the Starościńskie tor group in the northern part of the Rudawy Janowickie shown on the topographic map (A) and slope map (B)

niowo zgrupowanie skałek, zaś najbliższe skałki w kierunku zachodnim znajdują się w odległości około 250 m od szczytu. Stoki Janowickiego Grzbietu w rejonie Starościńskich Skał różnicują się pod względem spadku. Łagodniejsze są stoki wschodnie, których nachylenie sporadycznie tylko przekracza $15^{\circ}$ i rośnie do $20-25^{\circ}$ dopiero w odległości ponad $200 \mathrm{~m}$ od skałek. Stoki zachodnie (południowo-zachodnie) są bardziej strome, $z$ nachyleniami w zakresie $15-30^{\circ}$ i licznymi skalnymi ostańcami i progami. Zróżnicowanie spadków ma odzwierciedlenie w zróżnicowaniu utworów pokrywowych. Jakkolwiek bloki i głazy granitowe są powszechnie obecne na stokach grzbietów Rudaw Janowickich, to na wschodnich zboczach pokrywa głazowo-blokowa jest zwykle rozproszona, podczas gdy na zachodnich jest na znacznych powierzchniach zwarta, a bloki współwystępują z wychodniami granitowego podłoża.
Janowicki Grzbiet w rejonie Lwiej Góry jest zbudowany ze średnioziarnistej, porfirowatej odmiany granitu (Szałamacha 1969). Jego głównymi składnikami są kwarc, ortoklaz, plagioklaz i biotyt, tworzące kryształy zwykle o kilkumilimetrowej długości. Pojedyncze ortoklazy mogą osiągać długość do kilku centymetrów, ale egzemplarze o takich rozmiarach są znacznie rzadsze niż w odmianie gruboziarnistej. Granity Starościńskich Skał są poprzecinane skałami żyłowymi, głównie aplitami i pegmatytami. Aplity tworzą żyły o grubości od kilku centymetrów do blisko $1 \mathrm{~m}$, zorientowane różnokierunkowo, od poziomych do prawie pionowych. Granice $z$ otaczającym granitem średnioziarnistym są z reguły ostre, wskazujące na młodszy wiek aplitów krystalizujących $z$ resztkowej magmy granitowej. Rzadziej występują gruboziarniste pegmatyty, tworzące również gniazda 

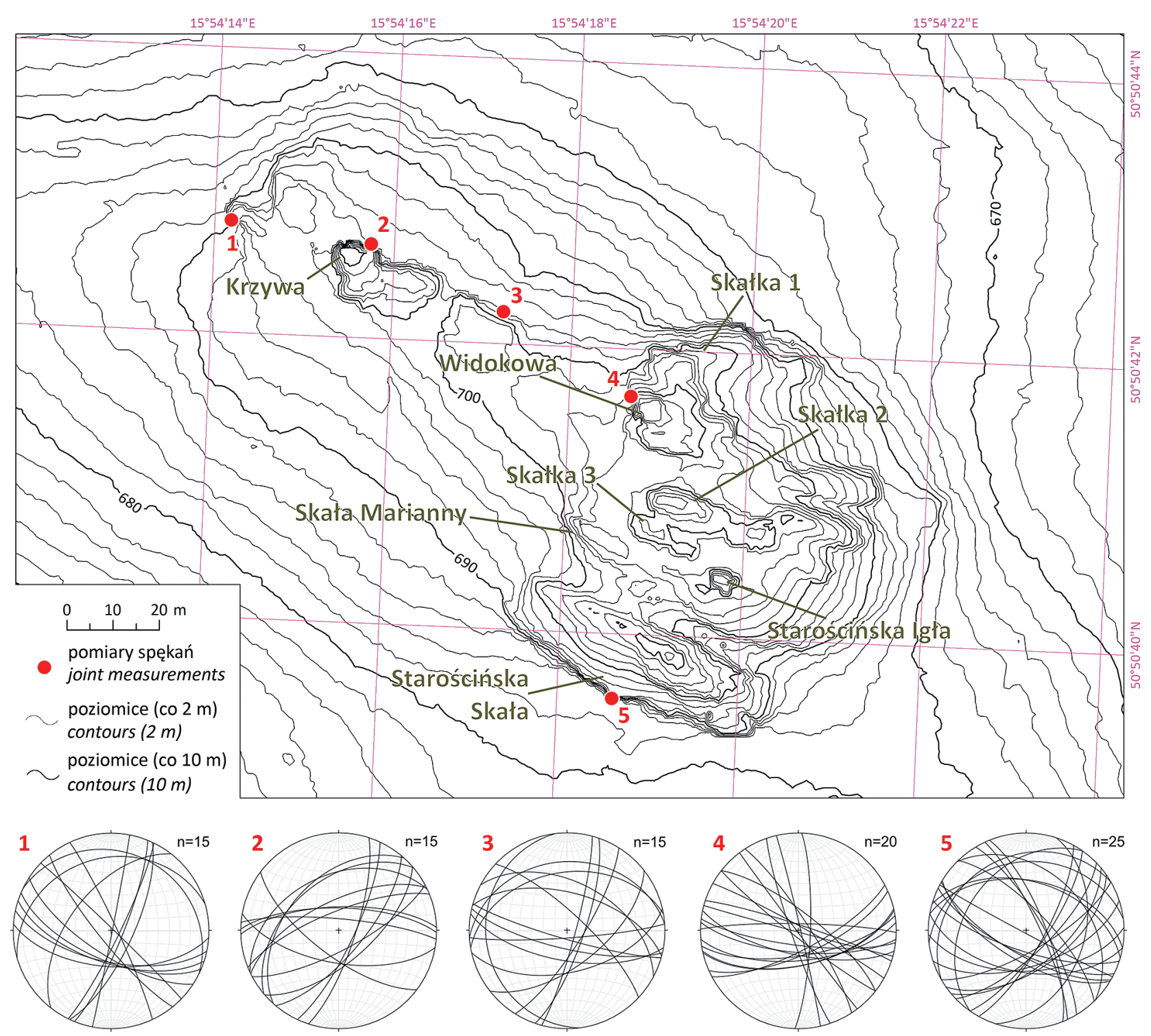

Ryc. 4. Mapa z zaznaczonymi stanowiskami pomiarowymi spękań oraz z nazwami skałek. W dolnej części przedstawiono diagramy spękań dla stanowisk

Fig. 4. Contour line map of the tor group, with location of joint measurement sites and tor names. At the bottom joint diagrams for the measurement sites are presented

i nieregularne w kształcie soczewy o długości do $1 \mathrm{~m}$ i szerokości do $20-30 \mathrm{~cm}$.

\section{Wyniki badań}

\section{Spękania}

Granit budujący najwyższą część Lwiej Góry jest poprzecinany przez kilka zespołów spękań. Najwyraźniej zarysowują się przewodnie spękania pionowe, rozciągające się wzdłuż linii grzbietowej o przebiegu WNW-ESE, których obecność jest szczególnie widoczna na stanowiskach 1, 3 oraz 5 (ryc. 4). W pó1nocno-zachodniej części Starościńskich Skał spę- kania te przecinają się pod kątem ostrym $z$ drugim zespołem spękań o przebiegu NNE-SSW, które zaznaczają się na ścianach skalnych w otoczeniu skałki Krzywa (stanowiska 1, 2 i 3). W północno-zachodniej strefie obecne są również spękania nachylone średnio pod kątem $45^{\circ}$ o kierunku upadu $320-350^{\circ}$, szczególnie widoczne na drugim stanowisku pomiarowym. Dużym zróżnicowaniem kierunków spękań charakteryzuje się południowa ściana skalnego wzniesienia Lwiej Góry (stanowisko 5, Starościńska Skała), na której powierzchnie nieciągłości reprezentują kilka odrębnych zespołów o kierunkach upadu $120-150^{\circ}$ oraz $320-10^{\circ}$, którego średni kąt zapadania wynosi $42^{\circ}$, w tym spękania pionowe lub nieznacznie pochylone o kierunkach upadu biegu WNW-ESE oraz NNE-SSW. 
Przedstawione zespoły spękań są reprezentowane przez różne kierunki, jednak na ich tle zarysowują się dominujące spękania. Główne kierunki pionowych nieciągłości, które pojawiły się na większości stanowisk pomiarowych, przebiegają na linii WNW-ESE i NNE-SSW. Zespoły te są prostopadłe względem siebie i razem tworzą system pionowych lub nieznacznie nachylonych powierzchni nieciągłości. Oprócz omówionych zespołów spękań w strukturze skał występują spękania koncentryczne, które zaznaczają się głównie $\mathrm{w}$ południowo-wschodniej partii wzniesienia, w jego krawędziowych partiach. Cios kopułowy, o miąższości nieprzekraczającej $1 \mathrm{~m}$, w niektórych miejscach nakłada się lub przechodzi w cios typu pokładowego.

\section{Morfologia "skalnego miasta”}

Starościńskie Skały rozciągają się wzdłuż osi grzbietowej Lwiej Góry na długości 180 m, na wysokości od 680 do 717 m n.p.m. W planie grupa skalna dzieli się wyraźnie na dwie części: na obszerną część południowo-wschodnią, w zarysie przypominającą prostokąt, oraz wąską część północno-zachodnią (ryc. 5). Szerokość kompleksu skalnego w części południowo-wschodniej wynosi $85 \mathrm{~m}$, zaś w północno-zachodniej $25 \mathrm{~m}$. W centralnej części Lwiej Góry znajduje się strefa o szerokości $23 \mathrm{~m}$, która pozbawiona jest wychodni skalnych, oddzielając tym samym dwie części „skalnego miasta”. W jej obrębie występują jedynie pojedyncze bloki o znacznych rozmiarach. Największą tego typu formę stanowi blok o wysokości 3,5 m, rozdzielony na dwie części przez szczelinę o długości $4,2 \mathrm{~m}$.

Część południowo-wschodnia w przekroju pionowym ma dwudzielny charakter. Dolna część, o wysokości względnej $24 \mathrm{~m}$, przypomina swym kształtem kopułę (ryc. 6) o stromo obciętych krawędziach po stronie południowo-zachodniej i północno-wschodniej. Z jej górnej powierzchni wyrastają elementy ostańcowe o wysokości do $15 \mathrm{~m}$. W planie obszar południowo-wschodni jest trójdzielny. Dwa głębokie obniżenia o przebiegu WNW-ESE rozdzielają wzniesienie na trzy pasy skałek - północny, środkowy oraz południowy. Obniżenia te mają postać żlebów o stromo opadających dnach, z których jeden jest skierowany na północny zachód, a pozostałe dwa na południowy wschód. Długość najszerszej (południowej) strefy obniżeń śródskałkowych wynosi łącznie $50 \mathrm{~m}$, przy szerokości dochodzącej do 4,5 m. Północny żleb osiąga długość $20,5 \mathrm{~m}$, przy czym w wyżej położonej części przechodzi on w obniżenie o szerokości $6 \mathrm{~m}$, rozdzielające północny i środkowy pas skałkowy.

Pasy skałek również mają wydłużone kształty, przebiegiem nawiązujące do kierunku spękań przewodnich WNW-ESE. Północny pas skałek opada w kierunku południowym ścianą o wysokości 5,5
Tabela 1. Morfometria wybranych form skałkowych (nazwy form i lokalizację przedstawiono na ryc. 4)

Table 1. Morphometry of the selected rock forms (names and localization are presented in Fig. 4)

\begin{tabular}{lcc}
\hline \multicolumn{1}{c}{ Formy skałkowe } & Wysokość [m] & Długość [m] \\
\hline Widokowa & 15,0 & - \\
Skałka 1 & 15,5 & - \\
Krzywa & 14,5 & - \\
Grzęda NS od Krzywej & 12,5 & 11,0 \\
Skałka 2 & 9,0 & 32,0 \\
Skałka Marianny & 11,0 & 13,5 \\
Skałka 3 & 5,0 & 18,0 \\
Starościńska Igła & 9,5 & - \\
Starościńska Skała & 30,0 & 58,0 \\
\hline
\end{tabular}

m, wyżej przechodząc w basztę (Widokowa), której szczytowe partie dochodzą do 15 m wysokości (tab. 1) oraz osiągają największą wysokość bezwzględną (717 m n.p.m.) w grupie Starościńskich Skał. Powierzchnie skalne odchodzące od baszty opadają dwoma stopniami w kierunku północnym i wschodnim. Szczyt baszty, na który prowadzą schodki wykute w stromych powierzchniach skalnych, pełni rolę punktu widokowego. Na północ od niej, w niższej pozycji topograficznej, znajduje się druga forma ostańcowa $\mathrm{w}$ postaci krótkiej grzędy o wysokości $15,5 \mathrm{~m}$, porozcinanej przez szereg równoległych spękań o rozstawie około $1 \mathrm{~m}$ i kierunku upadu na południowy zachód, a więc do środka kopuły. Wnętrze jednej ze szczelin rozcinających grzędę jest wypełnione przez bloki, z których jeden zawieszony jest pomiędzy ścianami skalnymi na wysokości $8 \mathrm{~m}$, tworząc niewielki tunel. Stromo opadające $\mathrm{w}$ kierunku północnym skalne stoki są zakończone ścianą okalającą wzniesienie (ryc. 5), której przewieszone fragmenty utworzyły w dolnej części duży okap skalny o głębokości $2 \mathrm{~m}$.

Centralny pas skałkowy tworzy szereg równoległych do siebie podłużnych ostańców skalnych (grzęd). Ich wysokości wahają się w przedziale 5-9 $\mathrm{m}$, zaś długości wynoszą od 13,5 do $32 \mathrm{~m}$ (ryc. 7). Formy te są rozdzielone przez szczeliny o różnej szerokości. Najwęższa z nich, o szerokości $0,5 \mathrm{~m}$ i długości 6,5 m, oddziela skałkę 2 od wychodni skalnej sąsiadującej $z$ nią od strony północno-wschodniej, przecinając jednocześnie prostopadłą do niej, niemal horyzontalnie zorientowaną żyłę aplitu o grubości 30 $\mathrm{cm}$. Kolejna stosunkowo wąska szczelina znajduje się między skałkami 2 i 3, przebiegając na linii WNWESE. Szczelina ta osiąga około $7 \mathrm{~m}$ długości i jest częściowo sklepiona przez duży blok granitu $(1,2 \mathrm{~m}$ długości) zaklinowany pomiędzy ścianami na wysokości $2 \mathrm{~m}$, tworzący krótki tunel podskalny (ryc. 8). Ostańcami, które zasługują na szczególną uwagę, są Starościńska Igła i Skałka Marianny. Pierwsza z nich to wysoka na 9,5 m izolowana i wąska skałka, górująca ponad pozostałymi formami $\mathrm{w}$ tej części wzniesie- 


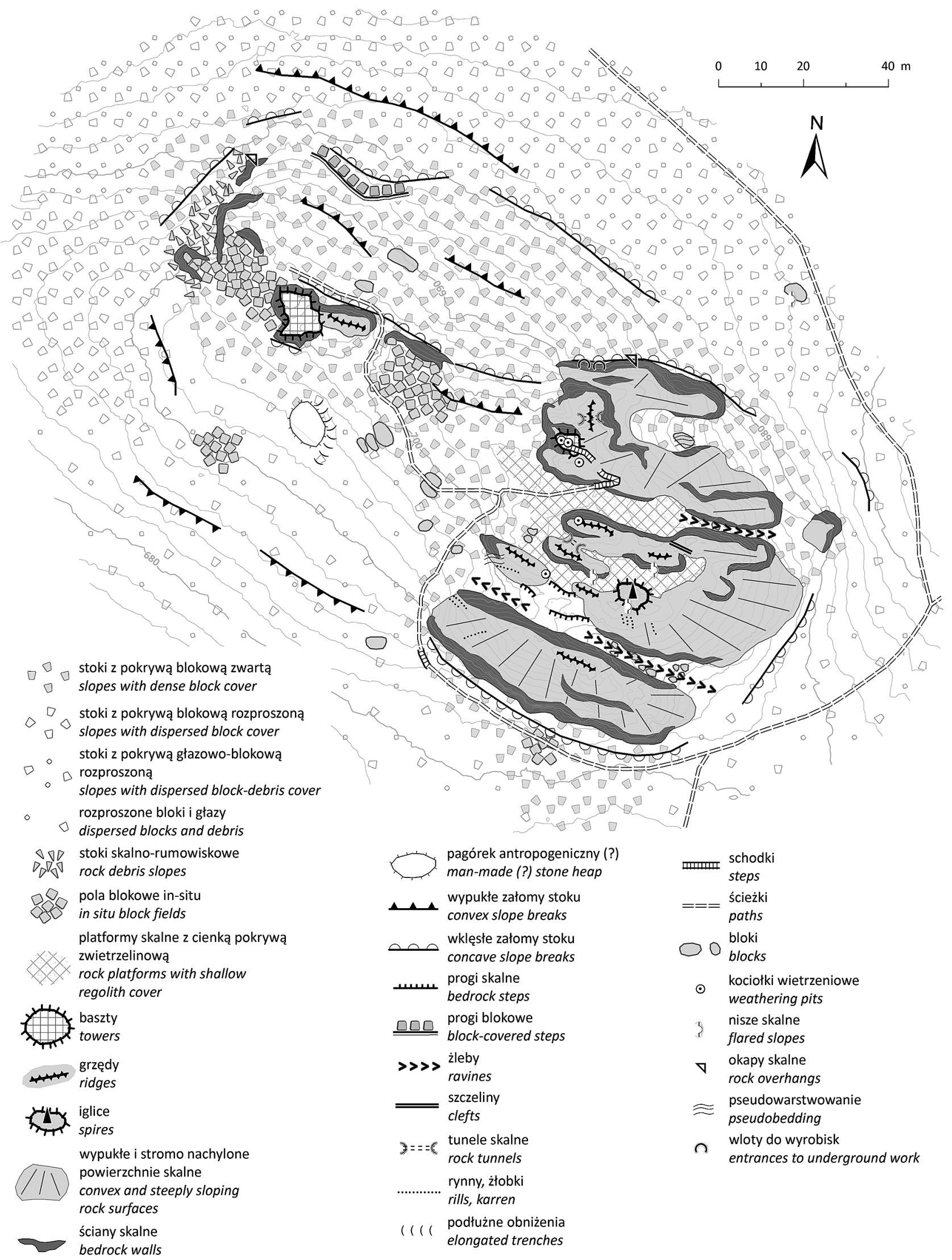

Ryc. 5. Mapa geomorfologiczna Starościńskich Skał

Fig. 5. Geomorphological map of the Starościńskie Skały 


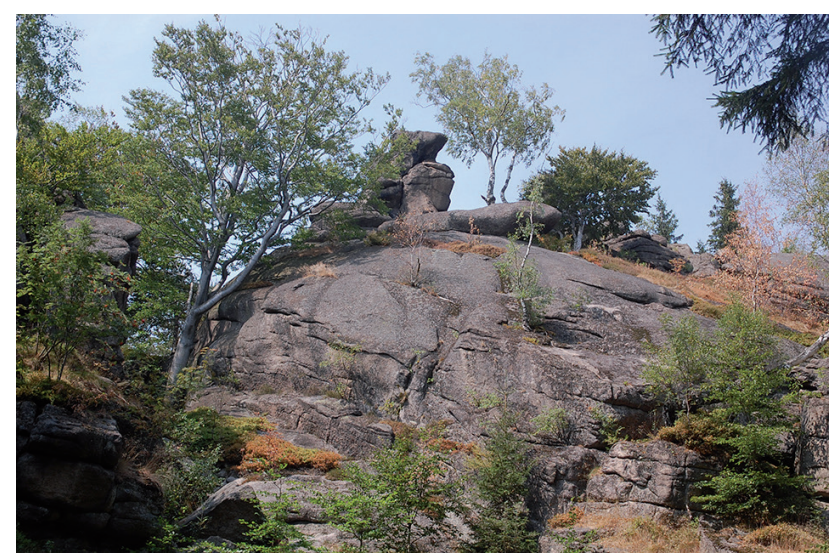

Ryc. 6. Widok na granitowe wzniesienie w kierunku północno-zachodnim (fot. P. Migoń)

Fig. 6. The dome of Starościńskie Skały towards north-west (photo P. Migoń)

nia (ryc. 9). Ściany iglicy są wygładzone i pozbawione ostrych krawędzi, jednak jej górne partie są mocno spękane horyzontalnie. Podstawa iglicy wznosi się na skalnym cokole o wysokości około $1 \mathrm{~m}$, który niżej, po stronie południowo-wschodniej, przechodzi w stromo pochylone, wypukłe powierzchnie skalne.

Skałka Marianny (niem. Mariannenfels) to asymetryczna grzęda skalna o długości $13,5 \mathrm{~m}$. Od strony południowej opada stromą ścianą o wysokości $11 \mathrm{~m}$ (ryc. 10), z kolei ściana po stronie północnej ma zaledwie 2,5 m wysokości. Górna partia skałki o grubości $6 \mathrm{~m}$ jest gęsto spękana (co 0,2-0,4 m) wzdłuż horyzontalnych powierzchni nieciągłości, tworząc strukturę określaną $\mathrm{w}$ granitach jako pseudowarstwowanie. Dolna część skałki ma bardziej masywną strukturę, bez widocznych spękań horyzontalnych lub pionowych. Skałka Marianny została częściowo przekształcona w wyniku działań człowieka w XIX w. Na południowej ścianie widnieją ślady dawnego napisu oraz wydrążonej półki skalnej, na której stała żeliwna figura lwa (Steć 1965).

Na południe od Skałki Marianny rozciąga się największa forma ostańcowa badanej grupy skalnej - Sta-

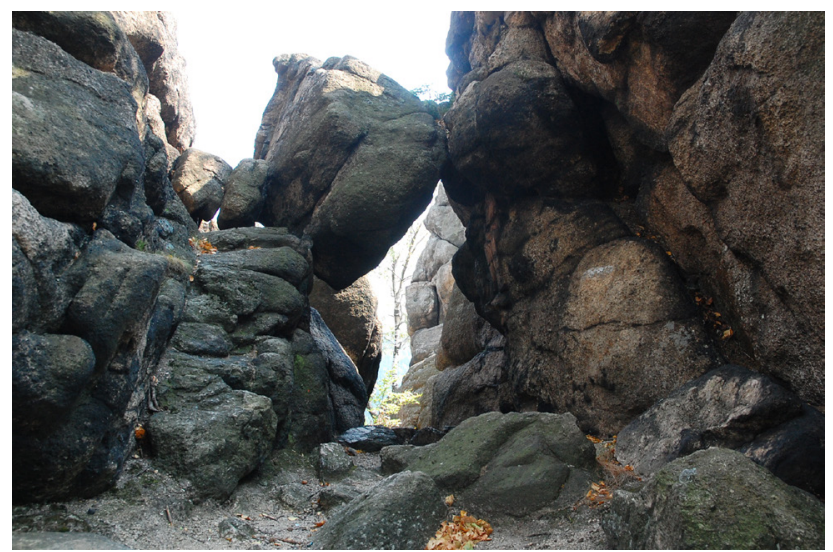

Ryc. 8. Tunel skalny z zawieszonym blokiem (fot. P. Migoń) Fig. 8. The rock tunnel with hanging block (photo P. Migoń)

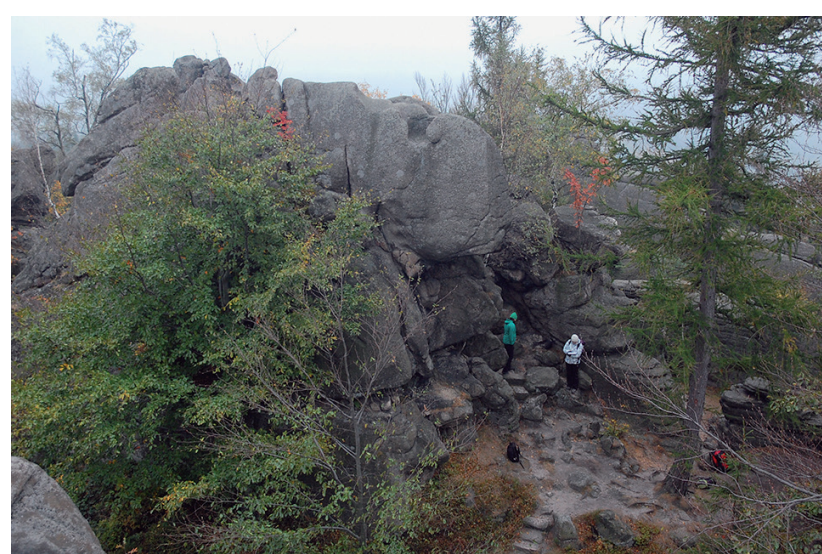

Ryc. 7. Grzęda w środkowym pasie skałkowym części południowo-wschodniej (fot. P. Migoń)

Fig. 7. Ridge tor in the central zone of the southeastern part (photo P. Migoń)

rościńska Skała (ryc. 11). Jest to zwarta forma skalna o długości 58 m i wysokości maksymalnej 30 m. Północna strona skałki jest wyznaczona przez urwisko, będące równocześnie południową ścianą żlebu rozcinającego skalne miasto, natomiast przeciwległa ściana opada stromo $\mathrm{w}$ kierunku południowo-zachod-

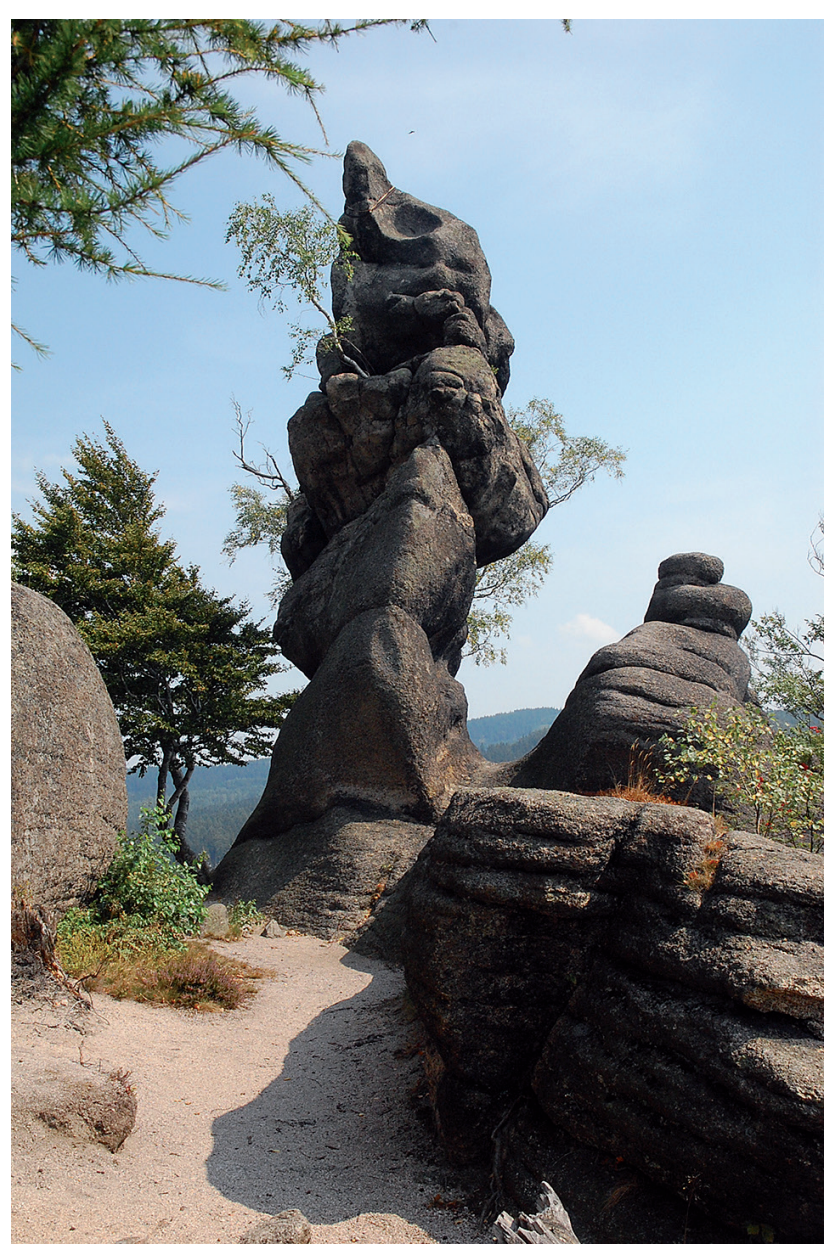

Ryc. 9. Starościńska Igła (fot. P. Migoń)

Fig. 9. The rock spire (Starościńska Igła) (photo P. Migoń) 


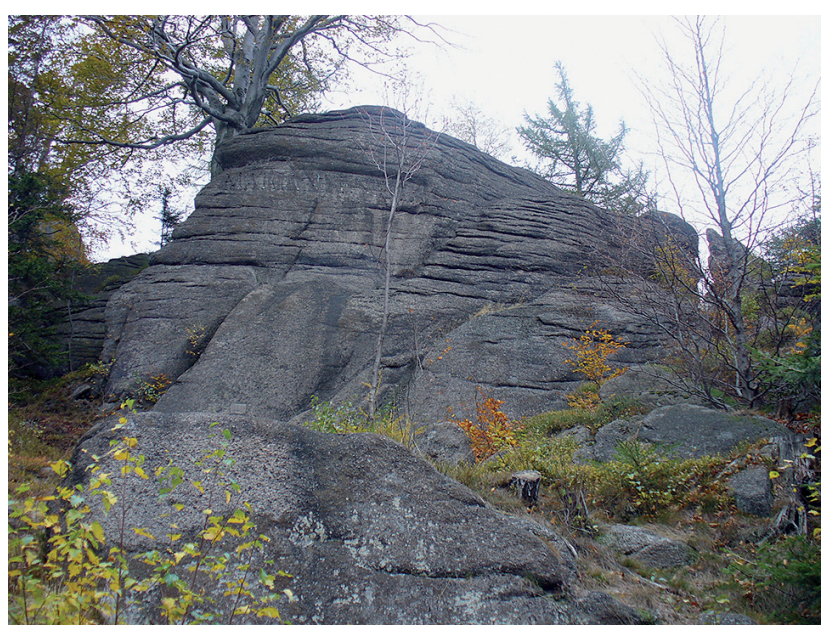

Ryc. 10. Skałka Marianny z charakterystycznym pseudowarstwowaniem (fot. A. Michniewicz)

Fig. 10. Marianna tor with typical pseudobedding (photo A. Michniewicz)

nim, zamykając tym samym całe skalne wzniesienie. W strukturze granitu widoczne są liczne zespoły spękań, które wpływają na morfologię ściany. W zachodniej części skałki odsłaniają się spękania koncentryczne, które stopniowo przechodzą niżej w system spękań prostokątnych. Spękania ortogonalne po stronie południowej przyczyniły się do powstania kilku płytkich przewieszek, których kształt nawiązuje ściśle do przebiegu powierzchni nieciągłości.

Morfologia form skalnych w południowo-wschodniej części Starościńskich Skał pokrywa się z biegiem głównych stref spękań o kierunku WNW-ESE, znajdujących się w odległości 7-20 m od siebie. Spękania przewodnie odzwierciedlają się szczególnie w morfologii dłuższych ścian ostańców oraz równoległych do nich liniowych obniżeń - żlebów, wyznaczając ich kierunek (rozciągłość). Drugorzędną rolę w kształtowaniu wyglądu skałek odgrywają spękania horyzontalne, które mimo licznego występowania na wielu skałkach nie przyczyniły się do powstania wyraźnej oddzielności blokowej. Górne fragmenty niektórych elementów ostańcowych mają gęsty cios pokładowy (pseudowarstwowanie).

Formy skałkowe w północno-zachodniej części Starościńskich Skał zajmują mniejszą powierzchnię w stosunku do obszaru południowo-wschodniego. Ostańce występują w pasie o szerokości około $15 \mathrm{~m}$ i kierunku WNW-ESE. Mniej więcej w połowie długości ciąg skałek jest rozcięty przez obniżenie o szerokości $2 \mathrm{~m}$ i rozciągłości NE-SW. Oddziela ono ścianę skalną po stronie południowo-wschodniej od skałek po stronie północno-zachodniej. Ściana ciągnie się na długości $17 \mathrm{~m}$ i osiąga wysokość $7 \mathrm{~m}$. Po stronie południowo-zachodniej przechodzi w łagodnie nachylony stok zajęty przez zwarte pole blokowe.

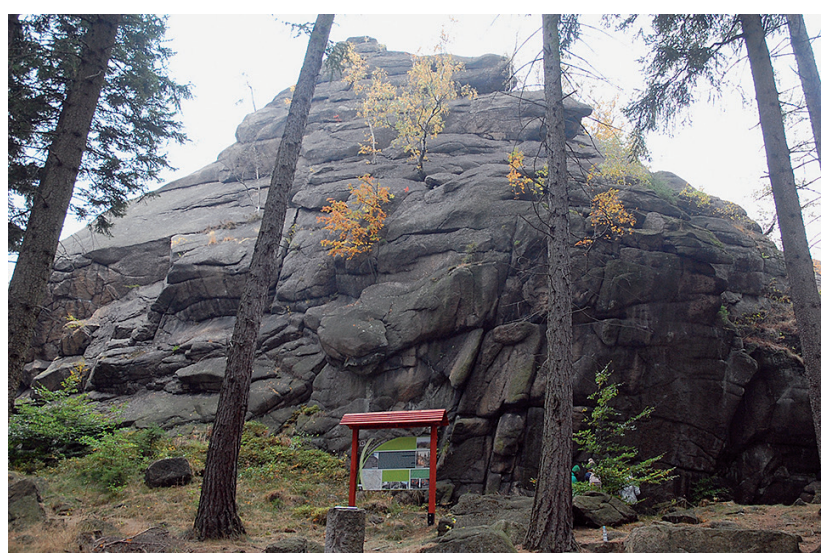

Ryc. 11. Największy ostaniec „skalnego miasta” - Starościńska Skała (fot. P. Migoń)

Fig. 11. The biggest residual form in the rock city located in the southeastern part of the group (photo P. Migoń)

Wszystkie bloki charakteryzują się zaokrąglonym kształtem, gładką powierzchnią oraz długością 1,5-3 $\mathrm{m}$.

Najwyższą ze skałek w tej części Starościńskich Skał jest baszta Krzywej osiągająca 14,5 m, która po stronie wschodniej przechodzi w grzędę skalną o długości $11 \mathrm{~m}$ i wysokości 12,5 m (ryc. 12). Basztę Krzywej tworzą dwa typy skał - jej środek w pionie zbudowany jest $z$ aplitu, natomiast krawędzie $z$ granitu porfirowatego. Żyła aplitu, odsłaniająca się na zachodniej ścianie Krzywej, osiąga miejscami $1 \mathrm{~m}$ szerokości i kończy się na górnej powierzchni baszty spiczastą aplitową przewieszką skalną. Morfologia ścian baszty jest urozmaicona przez powierzchnie nieciągłości o średnim upadzie $45^{\circ} \mathrm{w}$ kierunku NNW oraz spękań o upadzie $65^{\circ}$ i kierunku upadu SSW, które przyczyniły się do powstania przewieszonych fragmentów ścian w dolnych partiach skałki. Północno-zachodni kraniec Starościńskich Skał wyznaczają ściany skalne, których górne krawędzie są położone 20 m na północny zachód od skałki Krzywej i $11 \mathrm{~m}$ poniżej jej podstawy. Ściany osiągają 8-9 m wysokości, przy czym ich dolne partie są miejscami przykryte przez rumosz skalny.

Po północno-zachodniej stronie skałki Krzywej zalegają chaotycznie ułożone, ostrokrawędziste bloki (ryc. 5), z których największe mają ponad $3 \mathrm{~m}$ długości. Inne miejsce zalegania zwartej grupy bloków o podobnej morfologii znajduje się około $25 \mathrm{~m}$ na południowy zachód od Krzywej. Nieco bliżej, około $18 \mathrm{~m}$ na południe od baszty, znajduje się niewielka wypukłość terenu o owalnym kształcie i wysokości względnej 1,4 m. W bliskim otoczeniu, jak również na powierzchni wspomnianej formy, brak jest widocznych fragmentów skały podłoża. Od strony wschodniej wypukłość tę okala podłużne obniżenie o rynnowym kształcie. 


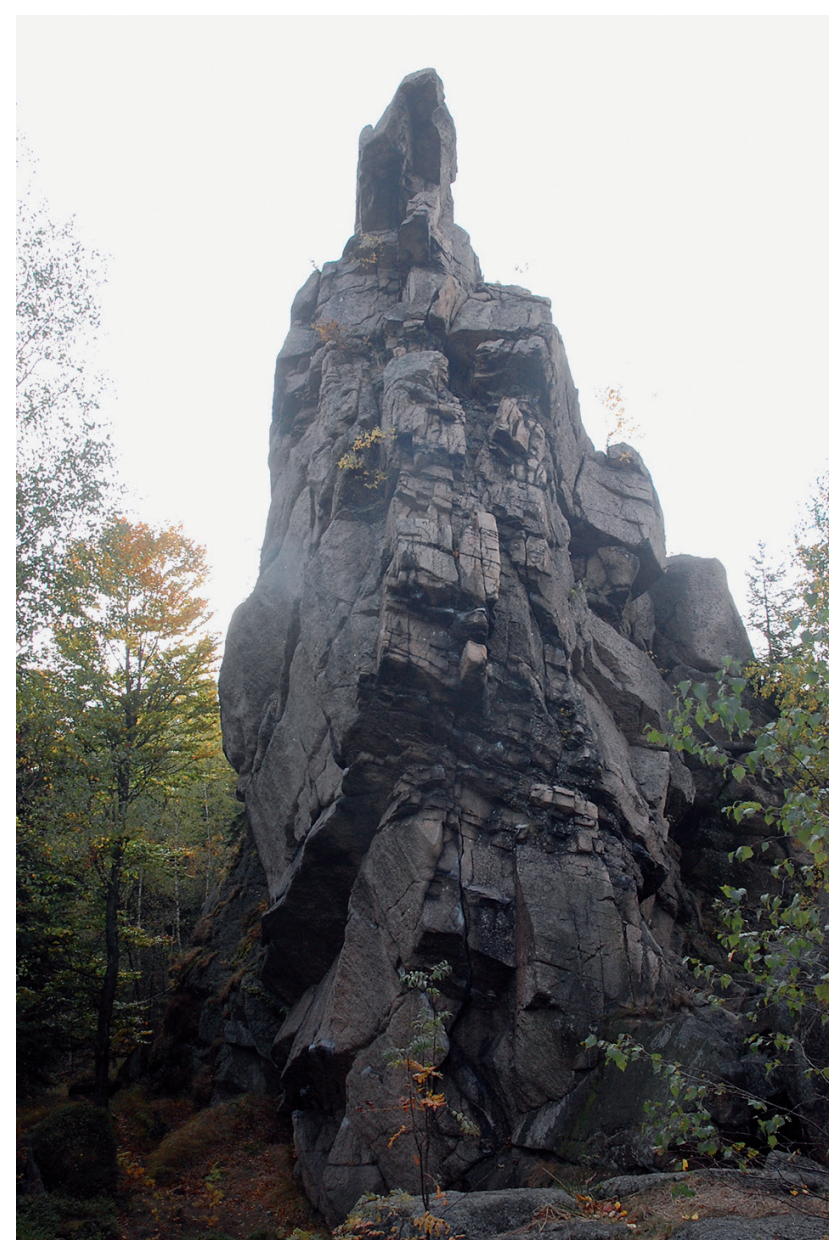

Ryc. 12. Skałka Krzywa w północno-zachodniej części (fot. P. Migoń)

Fig. 12. The Krzywa tor situated in the northwestern part (photo P. Migoń)

\section{Pokrywy stokowe}

Stoki w otoczeniu „skalnego miasta” są pokryte luźnym materiałem skalnym o zróżnicowanej zwartości i rozmiarach poszczególnych elementów (ryc. 5). W bezpośrednim sąsiedztwie form ostańcowych w części północno-zachodniej na stoku występuje zwarta pokrywa blokowa, której zasięg po północnej stronie skałek jest większy niż po stronie południowej i wynosi około $35 \mathrm{~m}$. Wraz z oddalaniem się od skałek charakter pokryw zmienia się na mniej zwarty. Do odległości około $25 \mathrm{~m}$ na zachód i południowy zachód od Krzywej rozpościera się rozproszona pokrywa blokowa, która wraz z odległością $\mathrm{w}$ kierunku południowo-wschodnim przechodzi w sporadycznie występujące bloki i głazy. Na północno-wschodnim stoku Lwiej Góry, poniżej linii wyznaczonej przez podłużny i wklęsły załom stoku, rozpościera się rozproszona pokrywa blokowo-głazowa. Stok poniżej tych załomów jest stosunkowo łagodny (ryc. 2), a jego nachylenie wynosi maksymalnie $10^{\circ}$.

W przypadku obszaru południowo-wschodniego zwarta pokrywa blokowa obejmuje północne i połu- dniowe (poniżej Starościńskiej Skały) obszary okalające wzniesienie. Nachylenie stoków w tych miejscach jest niewielkie i wynosi od 5 do $15^{\circ}$ (ryc. 2). $\mathrm{Na}$ stoku i spłaszczeniu grzbietowym po wschodniej stronie kopulastego wzniesienia zalegają głazy i bloki $\mathrm{w}$ dużym rozproszeniu.

Odmienną morfologią cechuje się stok o charakterze skalno-rumowiskowym, rozciągający się na długości około $30 \mathrm{~m}$ poniżej pionowych powierzchni skalnych na północno-zachodnim skraju Starościńskich Skał (ryc. 5). Rumosz składa się z chaotycznie zalegających na sobie, kanciastych bloków, które razem tworzą zwartą pokrywę o nachyleniu powyżej $35^{\circ}$ (ryc. 13). W obrębie pokrywy blokowej można wyróżnić mniejsze stopnie i progi o wysokości kilku metrów, będące wychodniami podłoża. Rozmiary poszczególnych bloków wynoszą około 2-4 m w dłuższej osi.

\section{Mikroformy powierzchni skalnych}

Etap terenowego kartowania geomorfologicznego pozwolił na identyfikację mniejszych form rzeźby granitowych powierzchni skalnych reprezentowanych przez cztery rodzaje mikroform: kociołki wietrzeniowe, rynny i żłobki oraz nisze kloszowe (ryc. 14). Ich obecność na omawianym terenie wzmiankowana była przez Czerwińskiego i Migonia (1993). Wszystkie rozpoznane formy znajdują się $\mathrm{W}$ południowo-wschodniej części obszaru badań (ryc. 5).

Kociołki wietrzeniowe (ang. weathering pits) stanowią charakterystyczny element mikrorzeźby powierzchni granitowych (Migoń 2006). Rozwijają się one na płaskich lub nieznacznie nachylonych powierzchniach zarówno wychodni skalnych, jak i rzadziej - bloków, przyjmując postać płaskodennych lub hemisferoidalnych zagłębień o zróżnicowanych wymiarach, od kilkunastu centymetrów do kilku metrów, przy głębokości zazwyczaj nieprzekraczającej $1 \mathrm{~m}$. O ile „wietrzeniowa geneza kociołków nie budzi już dziś żadnych wątpliwości" (Chmal 1974: 40), o tyle mechanizm rozwoju tych form nie został do końca poznany (Czerwiński 1985).

Żłobki (ang. karren) przyjmują postać linijnych zagłębień wykształconych na stromo nachylonych, często pionowych powierzchniach skalnych, co pozwala odróżnić je od rynien (ang. rills), które rozwijają się na powierzchniach o mniejszym nachyleniu, niekiedy prawie poziomych (Twidale 1982). Formy te występują najczęściej zespołowo. Żłobki biorą swój początek przeważnie na górnych krawędziach wychodni skalnych, stopniowo tracąc swą wyrazistość ku dołowi (Czerwiński, Migoń 1993). Pochodzenie tych form nie zostało jednoznacznie wyjaśnione i niewykluczone, że różne procesy mogą prowadzić do ich powstania. W przypadku rynien wskazuje się na rolę wody płynącej po powierzchni skały, choć pozostaje 


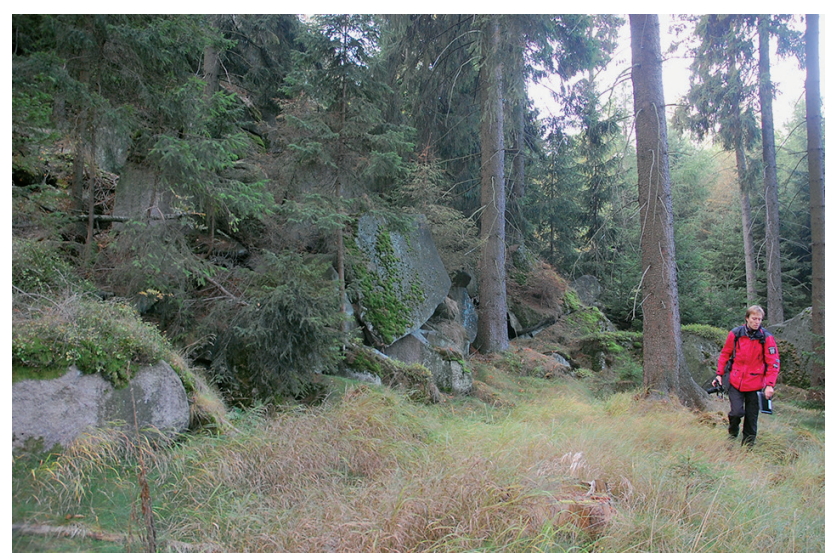

Ryc. 13. Stok skalno-rumowiskowy u podnóża ścian skalnych w części północno-zachodniej (fot. P. Migoń)

Fig. 13. Rock debris slope at the base of northwestern bedrock walls (photo P. Migoń)

kwestią nierozstrzygniętą, czy oddziałuje ona erozyjnie czy raczej usuwa tylko materiał ziarnisty przygotowany przez procesy wietrzeniowe (Migoń 2006).

Pod pojęciem nisz kloszowych (ang. flared slope) rozumieć należy występujące najczęściej u podstaw ścian skalnych lub pojedynczych bloków przewieszki i wcięcia nadające pionowym powierzchniom skalnym charakterystyczny profil litery „S”. Powstają one w wyniku szczególnie wydajnego podpowierzchniowego wietrzenia skał przebiegającego $\mathrm{w}$ warunkach wysokiej wilgotności gruntu, a następnie usunięcia zwietrzeliny. Ich obecność ma świadczyć o dawnym zasięgu frontu wietrzenia, a tym samym obniżaniu powierzchni wokół skałek (Twidale 1982). Miejsca, w których rozpoczynają się przewieszki, są zatem interpretowane jako dawne podstawy form skalnych. Nisze kloszowe mogą występować pojedynczo lub też tworzyć kilka poziomów, występując jedna nad drugą, co jest przesłanką do wnioskowania o kilkuetapowym usuwaniu pokrywy zwietrzelinowej z otoczenia formy rezydualnej.

Formami o wyraźnym wykształceniu na badanym obszarze są kociołki wietrzeniowe. Rozwinęły się one na poziomych powierzchniach w obrębie ostańców skalnych. Ich obecność nie została odnotowana w obrębie bloków zalegających na stokach.

Najgłębszy z kociołków rozwinął się jako pojedyncza, półotwarta forma po wschodniej stronie wychodni skalnej określanej jako Skałka Marianny, a więc przeciwnej do miejsca, w którym zaobserwować można pseudowarstwowanie $\mathrm{w}$ granicie. Ma on 0,45 m głębokości, osiągając długość 1,9 m przy maksymalnej szerokości około 0,9 m (na wysokości 0,1 m) (tab. 2). Szerokość dna, wypełnionego ziarnistą zwietrzeliną granitową, jest nieco mniejsza i wynosi $0,85 \mathrm{~m}$, zmniejszając się o blisko połowę $(0,4 \mathrm{~m})$ w kierunku wylotu.

Pojedyncza forma wietrzeniowa o znacznie bardziej kolistym zarysie wykształciła się nieco poni- żej platformy widokowej w kierunku południowo-wschodnim (ryc. 14A) i widoczna jest ze schodków, które na nią prowadzą. Podobnie jak wcześniej opisana, otwiera się ona ku krawędzi skałki. Jej dno stanowi powierzchnia skalna, bez większej ilość materiału zwietrzelinowego. Kociołek osiąga długość $1 \mathrm{~m}$ i maksymalną szerokość 0,7 m. Szerokość ta zmniejsza się w kierunku wylotu do około 0,3 m. Maksymalna głębokość misy $(0,45 \mathrm{~m})$ zanotowana została przy jej wschodniej krawędzi. Po stronie przeciwnej przekracza ona nieznacznie $0,2 \mathrm{~m}$, a cała forma jest asymetryczna w przekroju poprzecznym.

Kociołki wietrzeniowe znajdujące się na platformie widokowej wykształciły się $\mathrm{w}$ formie zespołowej (ryc. 14B). Wyróżnić tu można trzy wyraźne, połączone ze sobą formy oraz jedną mniejszą, nieckowatą, która znajduje się $\mathrm{w}$ inicjalnej fazie rozwoju. Forma ta, wysunięta najbardziej w kierunku północno-zachodnim, ma 0,3 m długości oraz $0,2 \mathrm{~m}$ szerokości. Podobnie kolisty zarys $(0,8 \mathrm{~m}$ długości i 0,75 m szerokości, głębokość około 0,3 m) przyjmuje sąsiedni kociołek otwierający się ku krawędzi w kierunku północnym, gdzie jego szerokość maleje do $0,4 \mathrm{~m}$. Kociołek ten łączy się z kolejnym, przylegającym do niego od południa, poprzez przewężenie o szerokości 0,2 m. Ten drugi, większy kociołek ma głębokość nieco ponad 0,25 m przy zbliżonych wartościach długości i szerokości, odpowiednio 1,05 m oraz $1 \mathrm{~m}$. W jego obrębie zauważyć można pęknię-

Tabela 2. Morfometria wybranych mikroform skałkowych (nazwy form i lokalizację przedstawiono na ryc. 4)

Table 2. Morphometry of the selected microforms (names and localization are presented in Fig. 4)

\begin{tabular}{|c|c|c|c|}
\hline \multirow{2}{*}{$\begin{array}{l}\text { Mikroformy } \\
\text { powierzchni } \\
\text { skalnych }\end{array}$} & $\begin{array}{c}\text { Głębokość } \\
\text { D }\end{array}$ & $\begin{array}{c}\text { Długość } \\
\mathrm{L}\end{array}$ & $\begin{array}{c}\text { Szerokość } \\
\text { W }\end{array}$ \\
\hline & \multicolumn{3}{|c|}{$[\mathrm{m}]$} \\
\hline $\begin{array}{l}\text { Kociołek na Skałce } \\
\text { Marianny }\end{array}$ & 0,45 & 1,9 & 0,85 \\
\hline $\begin{array}{l}\text { Kociołek } 1 \text { na } \\
\text { Widokowej }\end{array}$ & 0,23 & 1,0 & 0,70 \\
\hline $\begin{array}{l}\text { Kociołek } 2 \text { na } \\
\text { Widokowej }\end{array}$ & 0,28 & 0,8 & 0,75 \\
\hline $\begin{array}{l}\text { Kociołek } 3 \text { na } \\
\text { Widokowej }\end{array}$ & 0,26 & 1,0 & 1,05 \\
\hline $\begin{array}{l}\text { Kociołek } 4 \text { na } \\
\text { Widokowej }\end{array}$ & 0,40 & 1,2 & 0,60 \\
\hline $\begin{array}{l}\text { Rynna } 1 \text { na Skałce } \\
\text { Marianny }\end{array}$ & - & - & 0,30 \\
\hline $\begin{array}{l}\text { Rynna } 2 \text { na Skałce } \\
\text { Marianny }\end{array}$ & - & - & 0,40 \\
\hline $\begin{array}{l}\text { Żłobek } 1 \text { na } \\
\text { Starościńskiej } \\
\text { Ścianie }\end{array}$ & - & 2,0 & 0,15 \\
\hline $\begin{array}{l}\text { Żłobek } 2 \text { na } \\
\text { Starościńskiej } \\
\text { Ścianie }\end{array}$ & - & 1,8 & 0,45 \\
\hline
\end{tabular}


cie wyznaczające linię maksymalnej szerokości. Do takiego samego pęknięcia, biegnącego równolegle do poprzedniego, nawiązuje południowa krawędź formy wietrzeniowej. W obrębie jej niewyrównanego dna wyróżnić można jeszcze jedną mniejszą (włożoną) formę o owalnym zarysie. Omówiony powyżej kociołek poprzez rynnę długości około 1,3 m łączy się z misą kolejnego kociołka o długości 1,2 m oraz dwukrotnie mniejszej szerokości i maksymalnej głębokości $0,4 \mathrm{~m}$. Misa ta otwiera się ku południowo- -wschodniej krawędzi platformy widokowej przewężeniem o szerokości nieco poniżej $0,25 \mathrm{~m}$.

Rozległe zagłębienie o długości $2,9 \mathrm{~m}$ oraz szerokości 1,3 m, niemające jednak postaci klasycznego kociołka wietrzeniowego $\mathrm{z}$ racji braku wyraźnych górnych krawędzi, przylega ponadto bezpośrednio od południa do Starościńskiej Igły. Z platformy widokowej można ponadto zobaczyć otwarty kociołek wykształcony w obrębie górnej, północno-zachodniej krawędzi Skałki 2. Jest on trudno dostępny i autorzy
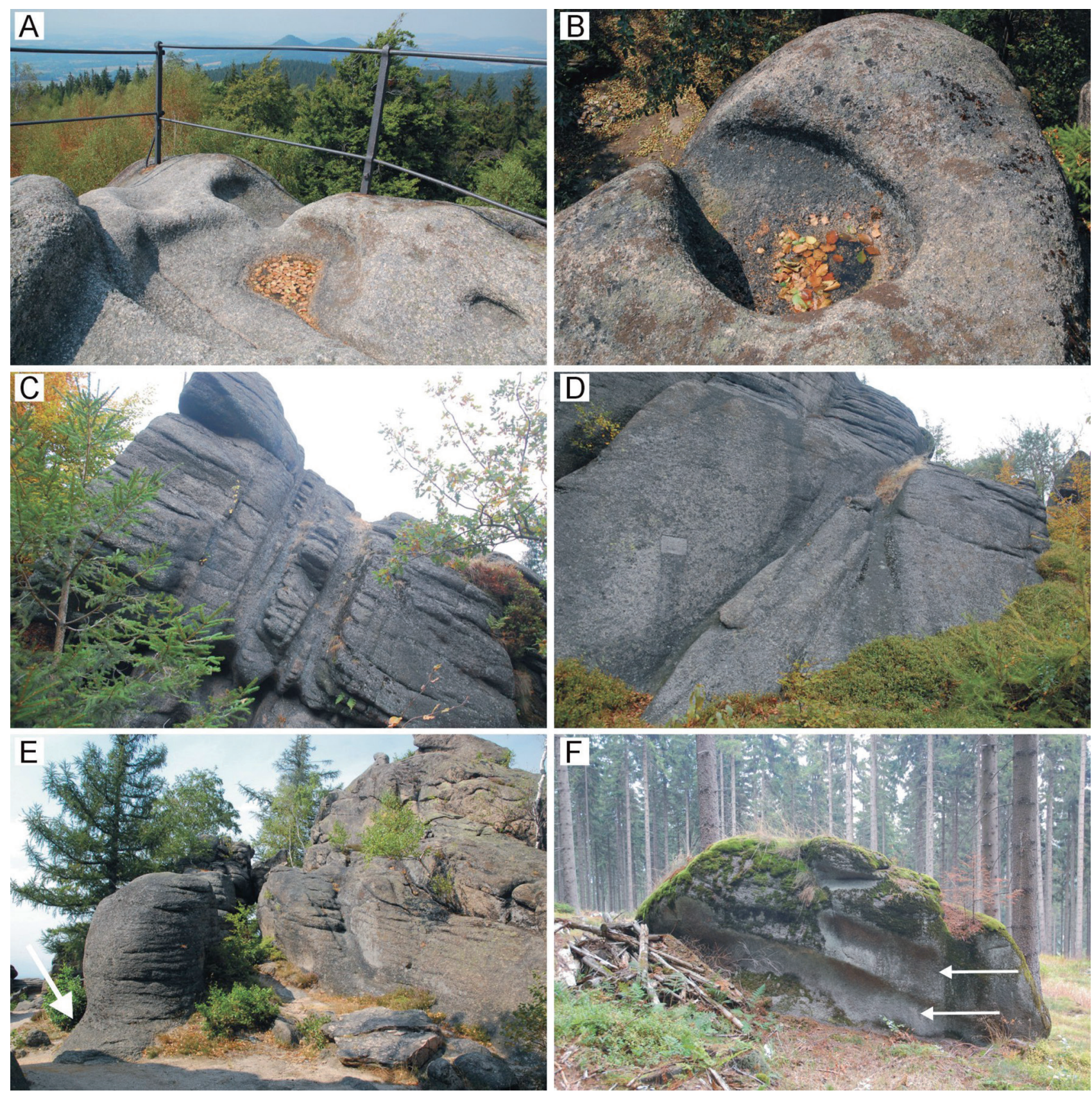

Ryc. 14. Mikroformy na powierzchniach skałek

A, B - kociołki wietrzeniowe na Widokowej, C - żłobki na Starościńskiej Skale, D - rynienki na Skałce Marianny, E - nisza kloszowa w części południowo-wschodniej, F - nisze kloszowe na bloku (fot. P. Migoń)

Fig. 14. Microforms on surfaces of the tors

A, B - weathering pits on the Widokowa tor, C - karren on the Starościńska tor, D - rills on the Marianna tor, E - flared slope in the southeastern part, F- flared slopes on the block (photo P. Migoń) 
nie mieli możliwości zmierzenia go, ale ma on przynajmniej 0,5 m głębokości i blisko $1 \mathrm{~m}$ średnicy.

W południowo-wschodniej części skalnego miasta, na wypukłych i stromo nachylonych powierzchniach skalnych (powyżej $60^{\circ}$ ), wykształciły się w kilku miejscach wydłużone zagłębienia określane jako żłobki, a na powierzchniach o mniejszym nachyleniu - rynny. Formy te nie występują pojedynczo, lecz w postaci kilku równolegle biegnących do siebie zagłębień. Stosunkowo łatwe do obserwacji są żłobki wykształcone na niemal pionowej ścianie skalnej w północno-zachodniej części Starościńskiej Ściany (ryc. 14C). Wyróżnić tu można co najmniej trzy takie formy o maksymalnej długości około $2 \mathrm{~m}$. Dwie węższe łączą się w dolnej części ściany skalnej w formę pojedynczą o szerokości około 0,3 m. Trzecia, najszersza $(0,5 \mathrm{~m})$, dzieli się odwrotnie w dolnej części na dwie formy mniejszej szerokości $(0,12$ i $0,28 \mathrm{~m})$ przecięte pojedynczym, wąskim na 0,12 m żebrem skalnym.

W obrębie Skały Marianny, na stoku o mniejszym nachyleniu poniżej ściany $z$ widocznym pseudowarstwowaniem, zauważalne są dwie rynny, rozpoczynające się wspólnym zagłębieniem w górnej części stoku (ryc. 14D). Bardziej wyraźna $z$ nich charakteryzuje się zmienną szerokością rosnącą w kierunku podstawy stoku, gdzie osiąga maksymalną wartość 0,4 m (tab. 2). Dalsze rynny, płytkie i słabo zarysowane, powstały w górnej części wschodniego skłonu grupy skalnej, poniżej Starościńskiej Igły.

Nisze kloszowe zaobserwowano zarówno u podstaw ścian skalnych, jak i pojedynczych bloków. W pierwszym przypadku wymienić należy trzy tego typu formy, wszystkie wykształcone wzdłuż południowych ścian skalnych: Starościńskiej Igły, Skałki 2 oraz Skałki 3 (ryc. 14E). Najlepiej ukształtowaną formą jest druga $z$ wymienionych. Przewieszka ta ciągnie się na długości około $8 \mathrm{~m}$, a jej wysokość od podstawy wynosi $2 \mathrm{~m}$. Głębokość niszy sięga maksymalnie $0,4 \mathrm{~m}$.

W jednym przypadku obecność nisz kloszowych została stwierdzona $\mathrm{w}$ obrębie pojedynczego bloku zalegającego na stoku o niewielkim nachyleniu (ryc. $14 \mathrm{~F}), \mathrm{w}$ odległości około $40 \mathrm{~m}$ na północny wschód od okapu skalnego rozwiniętego w obrębie eksponowanej na północ ściany Skałki 1. Można tu zaobserwować dwie nisze kloszowe ułożone jedna nad drugą, o wysokości około 0,6 m każda. Ich charakterystyczną cechą jest nachylenie pod kątem około $30^{\circ}$, zgodne $z$ kierunkiem nachylenia powierzchni stoku, przy czym kąt tego nachylenia jest jednak znacznie mniejszy i wynosi około $15^{\circ}$.

\section{Interpretacja i dyskusja}

Skałki na szczycie Lwiej Góry są pod względem morfologicznym dwudzielne, a czynnikiem, który ode- grał i nadal odgrywa decydującą rolę w kształtowaniu i powstaniu skałek, jest sieć spękań. Skałki są dość jednorodne pod względem litologicznym, natomiast podział Starościńskich Skał na dwie odrębne części nawiązuje wyraźnie do gęstości i geometrycznych cech układu spękań.

Charakterystyczną cechą części południowo-wschodniej jest obecność współśrodkowych, koncentrycznie występujących zakrzywionych powierzchni nieciągłości, które widoczne są w zewnętrznych partiach pasów skałkowych. Manifestują się one szczególnie w morfologii wypukłych, stromo nachylonych skalnych stoków, wyznaczając ich przebieg. Były one opisywane z niektórych wzgórz ostańcowych na obszarze Kotliny Jeleniogórskiej (Witosza, Kopki, Radlica; Migoń 1993) i mogą być utożsamiane $z$ sheeting joints $\mathrm{w}$ terminologii anglojęzycznej (Twidale i in. 1996). Powierzchnie spękań koncentrycznych są porozcinane przez stosunkowo głębokie strefy spękań pionowych o przebiegu WNW-ESE. Spękania pionowe przecinają granitowe wzniesienie w kilkunastometrowych odstępach, pomiędzy którymi znajdują się ostańce skalne o wydłużonych kształtach. Przecinające je spękania poprzeczne, tj. o kierunku NNE-SSW, występują rzadziej i w tej części Starościńskich Skał nie mają znaczącego wpływu na układ rezydualnych form skałkowych. Obecność głównej strefy spękań o kierunku NNE-SSW zaznacza się dopiero na północno-zachodniej krawędzi, która obcina granitową kopułę i wyznacza zasięg występowania skałek części południowo-wschodniej. Najmłodszy zespół nieciągłości tworzą horyzontalne spękania pokładowe, które rozcinają skałki w niewielkim odstępie co $20-30 \mathrm{~cm}$. Za główną przyczynę powstania tego rodzaju spękań uważa się stopniowe odciążanie i odprężanie granitu podczas odsłaniania powierzchni skalnych (Twidale, Vidal Romani 2005, 2010).

W odmienny sposób kształtuje się część północno-zachodnia Starościńskich Skał, która jest zbudowana $z$ bardziej spękanego granitu. Formy rezydualne i produkty wietrzenia mechanicznego $\mathrm{w}$ postaci bloków wskazują na gęstszą sieć spękań przewodnich w obydwu głównych kierunkach. Odległości pomiędzy poszczególnymi spękaniami $\mathrm{w}$ zespole WNW-ESE wynoszą 2-4 $\mathrm{m}$, natomiast $\mathrm{w}$ zespole NNE-SSW 1,5-3 m. Oprócz tego wpływ na morfologię ostańców skalnych ma zespół spękań o umiarkowanym kącie nachylenia, nieprzekraczającym $45^{\circ}$. Wpływ tych spękań przejawia się w dwustopniowej morfologii stoku, którego górną część tworzy skałka Krzywej; w pobliżu niej, w kierunki zachodnim rozwinęły się niżej położone ściany skalne.

Zróżnicowanie litologiczne Starościńskich Skał sprowadza się jedynie do obecności niewielkich żył aplitu, który występuje tu zarówno w pozycji wertykalnej, jak i horyzontalnej. Największa żyła aplito- 
wa, która miała istotny wpływ na morfologię skałek, znajduje się w obrębie baszty Krzywa. Aplit, mający drobnoziarnistą strukturę i będący skałą bardziej odporną na procesy niszczenia niż granit porfirowaty, przyczynił się zapewne do przetrwania tej wysokiej formy skałkowej.

Szczególną rolę spękań w kształtowaniu skałek granitowych masywu karkonosko-izerskiego dostrzeżono już we wcześniejszych pracach opisujących ich morfologię (Berg 1927, Bartošíková 1973). Wówczas potwierdzono, że sieć spękań zaobserwowanych na wychodniach skalnych pokrywa się $z$ systemem spękań LQS rozpoznanym przez Cloosa (1925). Jest on najwyraźniejszy i najbardziej regularny w granicie równoziarnistym, stąd typowy dla tej odmiany granitu prostopadłościenny kształt skałek.

Zagadnienie $\mathrm{w}$ rozwoju i powstania mezoform granitowych dla obszaru karkonosko-izerskiego zostało poruszone po raz pierwszy przez Jahna (1962). Autor ten przyjął dla Karkonoszy i Kotliny Jeleniogórskiej dwuetapowy model rozwoju rzeźby skałkowej, zaproponowany przez Lintona (1955) dla wyżyny Dartmoor w Wielkiej Brytanii. Model ten zakłada podpowierzchniowe wietrzenie chemiczne granitu W warunkach klimatu gorącego i wilgotnego, które jest szczególnie nasilone wzdłuż powierzchni spękań sięgających $\mathrm{w}$ głąb granitowego podłoża. W drugiej fazie zwietrzały materiał został usunięty przez nasilające się procesy denudacyjne, a mniej zwietrzałe fragmenty podłoża zostały odsłonięte w postaci skałek. Jako argumenty przemawiające za podpowierzchniowym kształtowaniem się skałek autor podał ich specyficzną morfologię, która nie mogła zostać ukształtowana w okresie zlodowacenia i w warunkach klimatu peryglacjalnego (np. zaokrąglone kształty bloków, brak śladów intensywnej dezintegracji mechanicznej wokół skałek), oraz przekształcenia chemiczne w pokrywach wietrzeniowych towarzyszących skałkom, które wskazywały na degradację granitu w klimacie gorącym. Teoria Jahna (1962) znalazła swoje potwierdzenie w latach 70. XX w., kiedy w wyniku prac drogowych w miejscowości Miłków, położonej w dnie Kotliny Jeleniogórskiej, doszło do odsłonięcia kilkumetrowego profilu wietrzeniowego, którego struktura, składająca się z trzonów bryłowych w otoczeniu drobnoziarnistej zwietrzeliny, była dowodem na podpowierzchniowe i selektywne wietrzenie masywu granitowego wzdłuż spękań.

Podobną koncepcję genezy wzgórz i powstałych na nich skałek granitowych w obrębie Kotliny Jeleniogórskiej przedstawił Migoń (1993, 1999). Autor ten za główny kierunek rozwoju rzeźby kształtujący pagórkowaty krajobraz kotliny przyjął etchplanację, charakteryzującą się naprzemiennie występującymi fazami wzmożonego wietrzenia i okresami usuwania zwietrzeliny. Wyodrębnienie się wzgórz granitowych z podłoża było ułatwione przez czynnik strukturalny, w którym istotną rolę odegrał koncentryczny system spękań charakterystyczny dla kopułowych wzgórz wyspowych (bornhardtów).

Analiza morfologii Starościńskich Skał pozwala na sformułowanie propozycji dotyczących ich możliwej genezy i ewolucji. Spękany granit prawdopodobnie początkowo ulegał wietrzeniu wzdłuż pionowych i poziomych systemów spękań, które rozcinały granitowy grzbiet (ryc. 15). Po częściowym odsłonięciu górnej partii wzniesienia podpowierzchniowe wietrzenie chemiczne znajdowało kontynuację w niższym położeniu wysokościowym w warunkach dużej wilgotności, o czym świadczy obecność nisz kloszowych w środkowym pasie skałkowym w części południowo-wschodniej, na wysokości $705 \mathrm{~m}$ n.p.m. W tym okresie część południowo-wschodnia musiała już mieć zarys swojej obecnej morfologii, a więc szerokie obniżenia i grzędy skalne, na których ścianach mogły rozwijać się nisze. W kolejnym etapie doszło do dalszego usunięcia zwietrzeliny aż do poziomu frontu wietrzenia, wypreparowania Starościńskich Skał oraz skałek sąsiadujących, znajdujących się poniżej wzniesienia. Położenie blo$\mathrm{ku} \mathrm{z}$ dwoma poziomami nisz kloszowych na stoku wschodnim, poniżej granitowej kopuły, świadczy o tym, że do intensywnego usuwania zwietrzałego materiału $z$ otaczających stoków dochodziło jeszcze przynajmniej dwukrotnie.
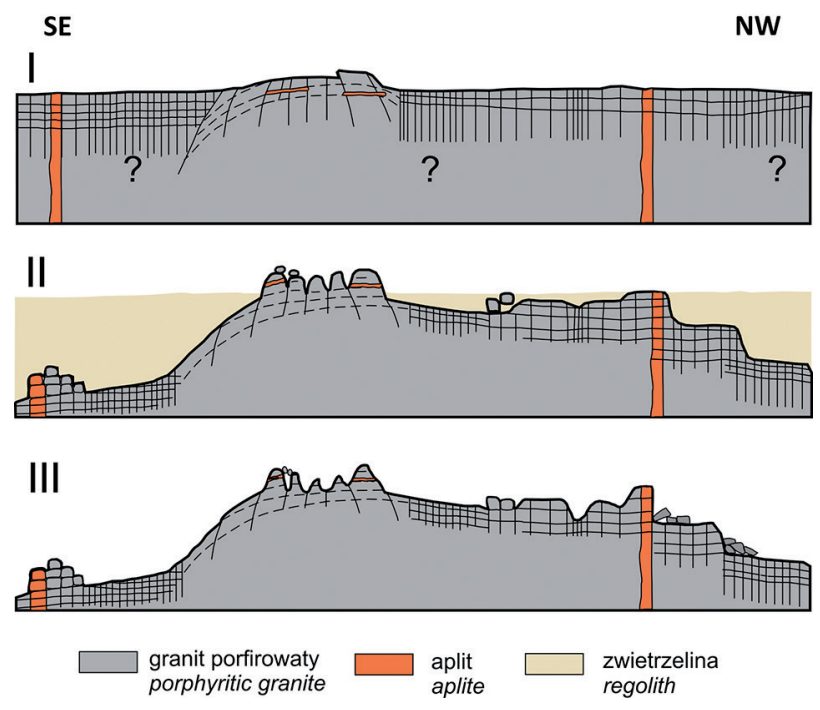

Ryc. 15. Koncepcja rozwoju szczytowej partii Lwiej Góry

I - sytuacja wyjściowa: podłoże granitowe spękane w różnym stopniu, II - podpowierzchniowy rozwój form rezydualnych na drodze selektywnego głębokiego wietrzenia, III - sytuacja obecna: wyeksponowanie skałek na powierzchni i degradacja wskutek procesów mechanicznego rozpadu

Fig. 15. The model of tor group evolution in the summit part of the Mt Lwia Góra

I - initial stage: fractured granite bedrock, II - subsurface evolution of residual landforms through selective deep weathering, III - contemporary situation: emergence of tors and their degradation due to physical weathering 
Po odsłonięciu skałek spod zwietrzeliny postępowała ich dalsza ewolucja w warunkach powierzchniowych. Wyraźna dwudzielność rzeźby Starościńskich Skał, wynikająca $z$ odmiennych cech systemów spękań, wskazuje na zróżnicowany rozwój tych dwóch części. Skałki w części południowo-wschodniej nie mają śladów przekształceń, które $\mathrm{w}$ znacznym stopniu miałyby zmodyfikować ich rzeźbę po odsłonięciu. O dużej stabilności tej części skalnego miasta świadczą kociołki wietrzeniowe $\mathrm{w}$ różnych stadiach rozwoju. Występowanie kociołków wietrzeniowych na górnych powierzchniach skał jest wyznacznikiem długotrwałej niezachwianej pozycji ostańców skalnych. Wokół tej części skałek nie ma również licznych bloków i głazów, które wskazywałyby na ich dalszy rozpad. Dna zagłębień i żlebów pokryte są jedynie niezbyt grubą warstwą zwietrzeliny ziarnistej („kaszy granitowej”), która sygnalizuje postępującą dezintegrację granularną. Z kolei morfologia części północno-zachodniej Starościńskich Skał wskazuje na znaczną degradację $\mathrm{w}$ porównaniu do części południowo-wschodniej. Wzdłuż ścian skalnych Krzywej i progu skalnego na zachód od niej rozpościerają się produkty mechanicznego rozpadu $\mathrm{w}$ postaci zwartych pokryw blokowych. Ilość materiału blokowego na stokach świadczy o tym, że znaczna część skałek w tej części grzbietu uległa degradacji i nie zachowała się do czasu obecnego. Szybsze tempo dezintegracji części północno-zachodniej należy wiązać z większą gęstością spękań pionowych i umiarkowanie nachylonych, podczas gdy koncentrycznie spękane stoki części południowo-wschodniej, rzadziej poprzecinane przez pionowy zespół spękań, cechują się większą odpornością na rozpad mechaniczny.

Czas odsłonięcia analizowanych skałek nie jest dokładnie znany, jednak ich pozostawanie $\mathrm{w}$ pozycji wododziałowej może sugerować stosunkowo wczesny wiek ekspozycji w stosunku do obszarów niżej położonych. W Rudawach Janowickich tempo denudacji na grzbietach zostało oszacowane na 2-3 razy większe niż w dolinach (Sobczyk 2012), natomiast próby datowań wieku ekspozycji powierzchni skalnych wykazały duże rozbieżności w przedziale czasowym (od kilku do kilkudziesięciu tysięcy lat).

„Skalne miasta" to rozbudowane mezoformy wykształcone w obrębie fragmentów stoku lub grzbietu. W ich skład wchodzą formy niższego rzędu, które razem tworzą skalny labirynt prowadzący pomiędzy ostańcami. Starościńskie Skały rozwinęły się na wzniesieniu, które połowicznie ma cios kopułowy. Przykładami wzgórz z charakterystycznymi spękaniami koncentrycznymi są Witosza (484 m n.p.m.) w Kotlinie Jeleniogórskiej i Chojnik (627 m n.p.m.) na Pogórzu Karkonoskim. Są to jednak izolowane formy, znacznie większe niż „skalne miasto”, opisywane $\mathrm{w}$ literaturze jako bornhardty, rozwinięte na drodze selektywnego wietrzenia i powstałe $\mathrm{w}$ ob- rębie nierównej powierzchni frontu wietrzenia masywu karkonosko-izerskiego. Zarówno na stokach Chojnika (o genezie tektoniczno-denudacyjnej), jak i na Witoszy rozwinęły się elementy rzeźby skałkowej, składające się z fragmentów wychodni podłoża oraz rumowiska bloków i głazów powstających wskutek ich rozpadu, które są związane $z$ degradacją tych granitowych kopuł (Migoń 1993).

Interesującymi obiektami o podobnym charakterze, które także znajdują się w obrębie masywu karkonosko-izerskiego, są skałki na północnym skraju Gór Izerskich w granicach Republiki Czeskiej. Na krawędzi morfologicznej o założeniach tektonicznych rozwinęły się Polední kameny (1006 m n.p.m.) (Simm 2009) - rozległa granitowa grupa skalna, składająca się z rozmaitych form ostańcowych i stromych granitowych ścian, opadających do doliny Białego Potoku (Bílý potok). Przykładem ostańców z innego obszaru granitowego Sudetów są wzgórza kopułowe i skałki masywu granitowego Žulovej (Štěpančíková, Rowberry 2008), które zostały opisane jako pozostałości selektywnego wietrzenia podpowierzchniowego, ściśle uwarunkowanego systemem spękań.

\section{Podsumowanie}

Starościńskie Skały to grupa skalna stanowiąca wyjątkowy w polskiej części masywu karkonosko-izerskiego przykład elementu pośredniego między wzgórzem kopułowym (bornhardtem) a typowymi dla regionu ostańcami skalnymi - skałkami. Starościńskie Skały wyróżniają się spośród innych form rezydualnych w Rudawach Janowickich dwupoziomową budową zarówno w przekroju pionowym, jak i w układzie przestrzennym. W planie kompleks skalny składa się z dwóch odmiennych morfologicznie części, które w wyniku różnic $\mathrm{w}$ systemie spękań odznaczają się nie tylko odmienną morfologią, ale też różnym stopniem degradacji. Rozwój skałek, uwarunkowany głównie siecią spękań pionowych oraz długim okresem ewolucyjnym, doprowadził do powstania dużej różnorodności i bogactwa form, od wysokich grzęd skalnych po mikrorzeźbę $\mathrm{w}$ postaci rynienek czy kociołków wietrzeniowych. Rozmaitość form budujących Lwią Górę pozwoliła na zaproponowanie legendy do szczegółowej mapy geomorfologicznej „skalnego miasta” oraz opracowanie pierwszej tak szczegółowej mapy dla dużego kompleksu skalnego w Sudetach. Zróżnicowanie mikroform w obrębie skałek sudeckich jest na ogół niewielkie (dominują kociołki wietrzeniowe), więc na tym tle Starościńskie Skały również stanowią rzadkość. Obecność mikroform wietrzeniowych posłużyła jako kryterium do oceny stabilności skałek oraz etapów ich rozwoju. 


\section{Podziękowania}

Autorzy składają podziękowania Annie Wysockiej za pomoc $\mathrm{w}$ trakcie prowadzenia badań terenowych oraz dwóm recenzentom za cenne uwagi do pierwszej wersji artykułu. Badania zostały przeprowadzone w ramach działalności statutowej Instytutu Geografii i Rozwoju Regionalnego Uniwersytetu Wrocławskiego (1015/S/2015). Informujemy, że wykorzystaliśmy dane cyfrowe LiDAR zgodnie $z$ licencją nr DIO. DFT.DSI.7211.1619.2015_PL_N wydaną w dniu 7 kwietnia 2015 r. przez Głównego Geodetę Kraju dla Wydziału Nauk o Ziemi i Kształtowania Środowiska Uniwersytetu Wrocławskiego.

\section{Literatura}

Allmendinger R.W., 2013. Stereonet Help - the user's manual for Stereonet 8.

Allmendinger R.W., Cardozo N.C., Fisher D., 2012. Structural Geology Algorithms: Vectors and Tensors. Cambridge University Press, Cambridge.

Bartošíková H., 1973. Morfologicky výrazné výchozy Krkonošského žulového masívu. Opera Corcontica 10: 71-91.

Berg G., 1927. Zur Morphologie des Riesengebirges. Zeitschrift für Geomorphologie 2: 1-20.

Chmal H., 1974. Geneza i wiek kociołków wietrzeniowych na skałkach Karkonoszy. Acta Universitatis Wratislaviensis 236, Prace Instytutu Geograficznego A1: 39-58.

Cloos H., 1925. Einführung in die tektonische Behandlung magmatischer Erschheinungen (Granittektonik). Teil I. Das Riesengebirge in Schlesien, Bau, Bildung und Oberflächengestaltung, Berlin.

Czeppe Z., 1952. Z morfologii Gór Stołowych. Ochrona Przyrody 20: 236-252.

Czerwiński J., 1985. Główne rysy rzeźby i rozwój geomorfologiczny. W: A. Jahn (red.), Karkonosze polskie. Ossolineum, Wrocław: 53-76.

Czerwiński J., Migoń P., 1993. Mikroformy wietrzenia granitów W masywie karkonosko-izerskim. Czasopismo Geograficzne 64(3-4): 265-284.

Dumanowski B., 1963. Stosunek rzeźby do struktury w granicie Karkonoszy. Acta Univ. Wratisl. 9, Studia Geograficzne 1:27-35.

Dumanowski B., 1968. The influence of petrographical differentiation of granitoids on landforms. Geographia Polonica 14: 93-98.

Jahn A., 1962. Geneza skałek granitowych. Czasopismo Geograficzne 33: 19-44.

Jahn A., 1974. Granite tors in the Sudeten Mountains. W: E.H. Brown, R.S. Waters (red.), Progress in Geomorphology. Institute of British Geographers, Special Publication 7: 53-61.

Linton D., 1955. The problem of tors. Geographical Journal 121: 470-487.

Migoń P., 1992. Granitowe formy skalne na Witoszy w Kotlinie Jeleniogórskiej - proponowany rezerwat przyrody nieożywionej. Chrońmy Przyrodę Ojczystą 48(1): 62-71.

Migoń P., 1993. Kopułowe wzgórza granitowe w Kotlinie Jeleniogórskiej. Czasopismo Geograficzne 64: 3-23.

Migoń P., 1996. Granite landscapes of the Sudetes Mountains some problems of interpretation: a review. Proceedings of the Geologists' Association 107: 25-38.

Migoń P., 1997. The geologic control, origin and significance of inselbergs in the Sudetes, NE Bohemian Massif, Central Europe. Zeitschrift für Geomorphologie 41: 45-66.
Migoń P., 1999. Znaczenie głębokiego wietrzenia w morfogenezie Sudetów. Przegląd Geograficzny 71: 59-75.

Migoń P., 2005. Karkonosze - rozwój rzeźby terenu. W: P. Mierzejewski (red.), Karkonosze - przyroda nieożywiona i człowiek. Wydawnictwo Uniwersytetu Wrocławskiego, Wrocław: 83-132.

Migoń P., 2006. Granite Landscapes of the World. Oxford University Press, Oxford.

Migoń P., 2007. Geomorphology of granite terrains in Poland. W: A. Kozłowski, J. Wiszniewska (red.), Granitoids in Poland. Archivum Mineralogiae Monograph 1, Komitet Nauk Mineralogicznych PAN \& Wydział Geologii UW: 355-366.

Migoń P., 2012. Granitowy krajobraz Kotliny Jeleniogórskiej dopełnienie Geoparku Karkonosze. Przegląd Geologiczny 60: 528-533.

Migoń P., Kasprzak M., Traczyk A., 2013. How high-resolution DEM based on airborne LiDAR helped to reinterpret landforms - examples from the Sudetes, SW Poland. Landform Analysis 22: 89-101.

Migoń P., Łętkowska A., 2015. Rudawski Park Krajobrazowy. Geologia - geomorfologia - geoturystyka. Dolnośląski Zespół Parków Krajobrazowych, Jelenia Góra.

Simm O., 2009. Tory Jizerskich hor. W: R. Karpaš (red.), Jizerské hory: O mapách, kamení a vodě. Nakladatelství RK, Liberec.

Sithole G., Vosselman G., 2004. Experimental comparison of filter algorithms for bare-Earth extraction from airborne laser scanning point clouds. ISPRS Journal of Photogrammetry and Remote Sensing 59: 85-101.

Sobczyk A., 2012. Datowanie procesów rzeźbotwórczych w Rudawach Janowickich i Kotlinie Kamiennogórskiej (Sudety) metodami termochronologii niskotemperaturowej oraz analizy radionuklidów kosmogenicznych. Niepublikowana praca doktorska. Instytut Nauk Geologicznych Uniwersytetu Wrocławskiego, Wrocław.

Stachowiak A., Cwojdziński S., Ihnatowicz A., Pacuła J., Mrázová Š., Skácelová D., Otava J., Pecina V., Rejchrt M., Skácelová Z., Večeřa J., 2013. Geostrada sudecka - przewodnik geologiczno-turystyczny. PIG-PIB, ČGS, Warszawa-Praga.

Steć T., 1965. Sudety Zachodnie. Cz. I. Wydawnictwo Sport i Turystyka, Warszawa.

Štěpančíková P., Rowberry M., 2008. Rock landforms that reflect differential relief development in the north-eastern sector of the Rychlebské hory and the adjacent area of Žulovská pahorkatina (SE Sudeten Mts, Czech Republic). Acta Geodynamica et Geomaterialia 5(151): 297-321.

Szałamacha J., 1969. Objaśnienia do Szczegółowej mapy geologicznej Sudetów. Arkusz Janowice Wielkie (M 33 - 44 Bd) 1:25 000. Wydawnictwo Geologiczne, Warszawa.

Twidale C.R., 1982. Granite Landforms. Elsevier, Amsterdam.

Twidale C.R., Vidal Romani J.R., 2005. Landforms and geology of the granite terrains. Balkema, Leiden.

Twidale C.R., Vidal Romani J.R., 2010. Structural or climatic control in granite landforms? The development of sheet structure, foliation, boudinage and related features. Cadernos Lab. Xeolóxico de Laxe Coruña 35: 189-208.

Twidale C.R., Vidal Romani J.R., Campbell E.M., Centeno J.D., 1996. Sheet fractures: response to erosional offloading or tectonic stress? Zeitschrift fur Geomorphologie Supplementband 106: 1-24.

Vítek J., 2016.. Adršpach-Teplice Rocks and Broumov Cliffs - Large Sandstones Rock Cities in the Central Europe. W: T. Pánek, J. Hradecký (red.), Landscapes and Landforms of the Czech Republic. Springer.

Wężyk P. (red.), 2014. Podręcznik dla uczestników szkoleń z wykorzystania produktów LiDAR. Informatyczny System Osłony Kraju przed nadzwyczajnymi zagrożeniami. Główny Urząd Geodezji i Kartografii, Warszawa: 328. 